\title{
Crystallographic identification of an unexpected by-product in an Ullman's reaction toward biphenyls: 1-(4-hexyloxy-3-hydroxyphenyl)ethanone
}

\author{
Veronica E. Manzano, Ricardo Baggio and Fabio D. Cukiernik
}

Acta Cryst. (2015). C71, 1022-1027

\begin{tabular}{|l|}
\hline IUCr Journals \\
CRYSTALLOGRAPHY JOURNALS ONLINE \\
Copyright C International Union of Crystallography \\
Author(s) of this paper may load this reprint on their own web site or institutional repository provided that \\
this cover page is retained. Republication of this article or its storage in electronic databases other than as \\
specified above is not permitted without prior permission in writing from the IUCr. \\
For further information see http://journals.iucr.org/services/authorrights.html
\end{tabular}




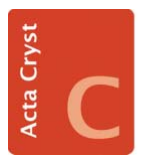

STRUCTURAL

CHEMISTRY

ISSN 2053-2296

\section{Crystallographic identification of an unexpected by-product in an Ullman's reaction toward bi- phenyls: 1-(4-hexyloxy-3-hydroxyphenyl)ethanone}

\author{
Veronica E. Manzano, ${ }^{\text {a }}$ Ricardo Baggio ${ }^{\mathrm{b} *}$ and Fabio D. Cukiernik ${ }^{\mathrm{a} *}$ \\ aDepartamento de Química Inorgánica, Analítica y Química Física/INQUIMAE-CONICET, Facultad de Ciencias Exactas y \\ Naturales, Universidad de Buenos Aires, Buenos Aires, Argentina, and ${ }^{\mathbf{b}}$ Gerencia de Investigación y Aplicaciones, Centro \\ Atómico Constituyentes, Comisión Nacional de Energía Atómica, Buenos Aires, Argentina. *Correspondence e-mail: \\ baggio@cnea.gov.ar,fabioc@qi.fcen.uba.ar
}

Edited by P. Fanwick, Purdue University, USA

Keywords: chemical identification; Ni-modified Ullmann reaction; biphenyls; 1-(4-hexyloxy-3hydroxyphenyl)ethanone; crystal structure; rearrangement.

CCDC reference: 1432541

Supporting information: this article has supporting information at journals.iucr.org/c

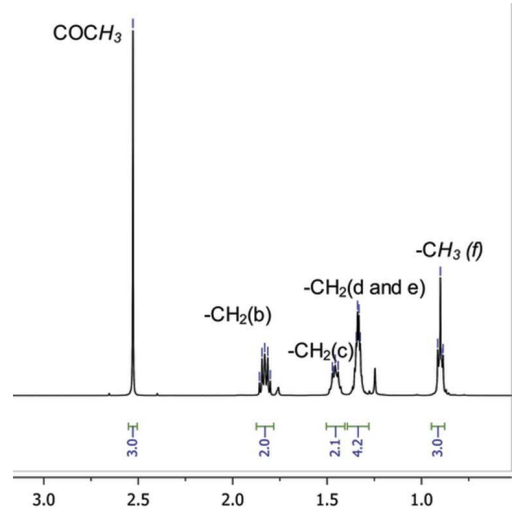

(C) 2015 International Union of Crystallography
The synthesis of 3,3'-diacetoxy-4,4'-bis(hexyloxy)biphenyl following the nickelmodified Ullmann reaction yielded a by-product which was identified successfully by crystallographic analysis as 1-(4-hexyloxy-3-hydroxyphenyl)ethanone, $\mathrm{C}_{14} \mathrm{H}_{20} \mathrm{O}_{3}$. This unexpected nonbiphenyl by-product exhibited IR, ${ }^{1} \mathrm{H}$ NMR, ${ }^{13} \mathrm{C}$ NMR and COSY (correlation spectroscopy) spectra fully consistent with the proposed structure. The compound crystallized in the orthorombic $P b c a$ space group, with two independent formula units in the asymmetric unit (one of which was slightly disordered), and showed a supramolecular architecture in which molecules linked by hydroxy-ethanone $\mathrm{O}-\mathrm{H} \cdots \mathrm{O}$ interactions are organized in columns separated by the aliphatic tails.

\section{Introduction}

Substituted triphenylenes are the most extensively studied class of compounds that give rise to columnar liquid crystalline (LC) phases (Pal et al., 2013; Bushby \& Kawata, 2011). In this context, we recently proposed a synthetic pathway to triphenylenes exhibiting terminal functionalizations at the 2-and 7-positions (Zelcer et al., 2013), which allows their incorporation into extended systems like oligomers and polymers (Zelcer et al., 2007, 2013), with the bridging chains attached to the furthest separated positions ( 2 and 7 ) of the triphenylene units. This synthetic pathway involved substituted 4,4'diacetoxy-3,3'-bis(hexyloxy)biphenyl (Zelcer et al., 2013) as a key intermediate compound. We then decided to explore the influence of the point of attachment of substituents on the LC properties of such polymers, looking first for materials derived from 3,6-difunctionalized triphenylenes. In order to synthesize these compounds, our synthetic strategy also involved a key intermediate biphenyl, in the present case, bearing acetoxy protecting groups at the 3 - and $3^{\prime}$-positions, as shown in the Scheme. The key reaction for the synthesis of biphenyl (V) involved a nickel-catalyzed Ullmann reaction (Zembayashi et al., 1977; Hong et al., 2001). The products were fully characterized by ${ }^{1} \mathrm{H}$ NMR, ${ }^{13} \mathrm{C}$ NMR, FT-IR, elemental analysis and HRMS.

During the course of the Ullmann reaction, we also isolated a second product and attempted to identify it using the same set of techniques. We envisaged different possible substituted biphenyls, but none of the proposed structures could explain the experimental spectra of the product obtained. We then succeeded in crystallizing it and solved its molecular structure. Unexpectedly, the compound was not a substituted biphenyl, 
but a rearranged phenyl product, namely 1-(4-hexyloxy-3hydroxyphenyl)ethanone, (I) (see Scheme). We report herein the crystal and molecular structure of (I), along with its completely assigned ${ }^{1} \mathrm{H}$ NMR, ${ }^{13} \mathrm{C}$ NMR, COSY (correlation spectroscopy) and FT-IR spectra, and suggest a possible mechanism for its formation.

\section{Experimental}

All chemical precursors were purchased from Sigma-Aldrich and used without further purification. Operations under an inert atmosphere were carried out using standard Schlenk techniques. ${ }^{1} \mathrm{H}$ NMR spectra were measured on a Bruker AM500 spectrometer, using $\mathrm{CDCl}_{3}$ as solvent and its residual peaks as internal references (7.26 p.p.m. for ${ }^{1} \mathrm{H}$ ). Differential scanning calorimetry (DSC) was performed with a Shimadzu DSC-50 apparatus. Elemental analysis was carried out at UMYMFOR, Conicet, and Department of Organic Chemistry, FCEN, UBA, Argentina.

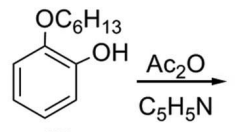

(II)

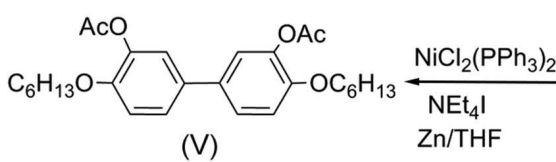

(V)

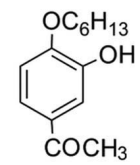

(I)

\subsection{Synthesis and crystallization}

2.1.1. Synthesis of 2-(hexyloxy)phenyl acetate, (III). 2-(Hexyloxy)phenol, (II) (10 g, $0.05 \mathrm{~mol})$, was acetylated with acetic anhydride $(20 \mathrm{ml})$ and pyridine $(20 \mathrm{ml})$ at room temperature for $16 \mathrm{~h}$. Examination by thin-layer chromatography (TLC; cyclohexane $/ \mathrm{CH}_{2} \mathrm{Cl}_{2}, 1: 1 \mathrm{v} / \mathrm{v}$, stain $\left.\mathrm{I}_{2}\right)$ showed the complete conversion of (II) $\left(R_{\mathrm{F}}=0.46\right)$ into a slower-moving product $\left(R_{\mathrm{F}}=0.35\right)$. The mixture was concentrated and (III) was obtained as an oily syrup (yield $11.4 \mathrm{~g}, 97 \%) ;{ }^{1} \mathrm{H} \mathrm{NMR}\left(\mathrm{CDCl}_{3}, 500 \mathrm{MHz}\right): \delta 7.18$ (ddd,1H, ArH), 7.06 (dd, 1H, J = 7.75, $1.75 \mathrm{~Hz}, \operatorname{ArH}), 6.97$ (dd, $1 \mathrm{H}, J=8.25,1.25 \mathrm{~Hz}, \mathrm{Ar} H), 6.93(t d, 1 \mathrm{H}, J=7.5,1.5 \mathrm{~Hz}, \operatorname{Ar} H)$, $3.98\left(t, 2 \mathrm{H}, J=6.5 \mathrm{~Hz}, \mathrm{CH}_{2} \mathrm{O}-\right), 2.31\left(\mathrm{~s}, 3 \mathrm{H}, \mathrm{CH}_{3} \mathrm{COO}-\right), 1.78(\mathrm{~m}$, $\left.2 \mathrm{H}, \mathrm{CH}_{2} \mathrm{CH}_{2} \mathrm{O}-\right), 1.48\left[\mathrm{~m}, 2 \mathrm{H}, \mathrm{CH}_{2}\left(\mathrm{CH}_{2}\right)_{2} \mathrm{O}-\right], 1.39-1.36[m, 4 \mathrm{H}$, $\left.\left(\mathrm{CH}_{2}\right)_{2}\left(\mathrm{CH}_{2}\right)_{2} \mathrm{O}-\right], 0.96\left[t, 3 \mathrm{H}, J=7.0 \mathrm{~Hz},-\mathrm{O}\left(\mathrm{CH}_{2}\right)_{5} \mathrm{CH}_{3}\right]$.

2.1.2. Synthesis of 5-bromo-2-(hexyloxy)phenyl acetate, (IV). Compound (III) ( $3.0 \mathrm{~g}, 0.013 \mathrm{~mol})$ was placed in a roundbottomed two-necked flask equipped with a pressure-compensated funnel and $\mathrm{CH}_{2} \mathrm{Cl}_{2}(7.5 \mathrm{ml})$ was added. The flask was cooled to $273 \mathrm{~K}$ in an ice bath and a vessel bubbler with an $\mathrm{Na}_{2} \mathrm{CO}_{3}$ solution was placed in the remaining neck. Then a solution of $\mathrm{Br}_{2}(0.75 \mathrm{ml}, 0.015 \mathrm{~mol})$ in $\mathrm{CH}_{2} \mathrm{Cl}_{2}(2.8 \mathrm{ml})$ was introduced into the funnel and added dropwise under continuous stirring over a period of $90 \mathrm{~min}$, resulting in a red solution. The ice bath was removed and the solution stirred until it remained colourless. When TLC (cyclohexane-dichloromethane, 1:1 v/v, $\mathrm{UV}$ and $\mathrm{FeCl}_{3}$ stain) showed the complete conversion of the starting material $\left(R_{\mathrm{F}}=0.48\right)$ into a faster-moving spot $\left(R_{\mathrm{F}}=0.55\right)$, dichloromethane $(50 \mathrm{ml})$ was added to the mixture and the organic phase was washed with $\mathrm{NaHCO}_{3}$ (ss) and water, then dried over $\mathrm{Na}_{2} \mathrm{SO}_{4}$, filtered and evaporated under reduced pressure. The product was purified by chromatographic column [cyclohexane $\rightarrow$ cyclohexane$\left.\mathrm{CH}_{2} \mathrm{Cl}_{2}(95: 5 \mathrm{v} / v)\right]$. Compound (II) was a colourless oil (yield $2.9 \mathrm{~g}, 71 \%) ;{ }^{1} \mathrm{H}$ NMR $\left(500 \mathrm{MHz}, \mathrm{CDCl}_{3}\right): \delta 7.28(d d, 1 \mathrm{H}, J=$ 8.7, 2.4 Hz, ArH), $7.17(d, 1 \mathrm{H}, J=2.4 \mathrm{~Hz}, \operatorname{Ar} H), 6.81(d, 1 \mathrm{H}, J=$ $8.8 \mathrm{~Hz}, \mathrm{Ar} H), 3.94\left(t, 2 \mathrm{H}, J=6.5 \mathrm{~Hz}, \mathrm{CH}_{2} \mathrm{O}-\right), 2.29(s, 3 \mathrm{H}$, $\left.\mathrm{CH}_{3} \mathrm{COO}-\right), 1.75\left(\mathrm{~m}, 2 \mathrm{H}, \mathrm{CH}_{2} \mathrm{CH}_{2} \mathrm{O}-\right), 1.45-1.30[\mathrm{~m}, 6 \mathrm{H}$, $\left.\mathrm{O}\left(\mathrm{CH}_{2}\right)_{2}\left(\mathrm{CH}_{2}\right)_{3} \mathrm{CH}_{3}\right], 0.90\left[t, 3 \mathrm{H}, J=7.0 \mathrm{~Hz}, \mathrm{O}\left(\mathrm{CH}_{2}\right)_{5} \mathrm{CH}_{3}\right]$; ${ }^{13} \mathrm{C} \mathrm{NMR}\left(\mathrm{CDCl}_{3}, 125.7 \mathrm{MHz}\right): \delta 168.7\left(-\mathrm{OCOCH}_{3}\right), 150.2$, 140.8, 129.7, 126.1, 114.7, 111.9 (Ar), $69.1\left(\mathrm{OCH}_{2}\right), 31.6,29.2$, 25.7, $22.7\left[\mathrm{OCH}_{2}\left(\mathrm{CH}_{2}\right)_{4} \mathrm{CH}_{3}\right], 20.6\left(-\mathrm{OCOCH}_{3}\right), 14.1\left[\mathrm{OCH}_{2}-\right.$ $\left(\mathrm{CH}_{2}\right)_{4} \mathrm{CH}_{3}$ ]. FT-IR diagnostic bands: $3074\left(\nu \mathrm{C}_{\text {aromatic }}-\mathrm{H}\right)$, $2958\left(\nu \mathrm{CH}_{3}{ }^{\text {assym }}\right), 2931\left(\nu \mathrm{CH}_{2}{ }^{\text {assym }}\right), 2872\left(\nu \mathrm{CH}_{3}{ }^{\text {sym }}\right), 2859$ $\left(\nu \mathrm{CH}_{2}{ }^{\mathrm{sym}}\right), 1776 \mathrm{~cm}^{-1}(\nu \mathrm{C}=\mathrm{O})$. Microanalysis found (calculated) for $\mathrm{C}_{14} \mathrm{H}_{19} \mathrm{BrO}_{3}$ (\%): C 54.2 (53.3), $\mathrm{H} 6.0$ (6.0).

2.1.3. Synthesis of $3,3^{\prime}$-diacetoxy-4, $4^{\prime}$-bis(hexyloxy)biphenyl, (V), and 1-(4-hexyloxy-3-hydroxyphenyl)ethanone, (I). In a Schlenk round-bottomed flask, $\mathrm{NiCl}_{2}\left(\mathrm{PPh}_{3}\right)_{2}(0.55 \mathrm{~g}$, $0.84 \mathrm{mmol})$ and $\mathrm{N}\left(\mathrm{CH}_{2} \mathrm{CH}_{3}\right)_{4} \mathrm{I} \quad(0.23 \mathrm{~g}, 0.89 \mathrm{mmol})$ were added, dried and degassed, applying three cycles of vacuum/ argon. Then, under an argon atmosphere, a suspension of $\mathrm{Zn}$ dust $(1.1 \mathrm{~g}, 17 \mathrm{mmol})$ in dried and deoxygenated tetrahydrofuran (THF, $2 \mathrm{ml}$ ) was added. The mixture was stirred for $30 \mathrm{~min}$. In another Schlenk flask, a solution of deoxygenated (IV) $(2.5 \mathrm{~g}, 7.8 \mathrm{mmol})$ in THF $(11 \mathrm{ml})$ was added to the first flask and the reaction mixture was stirred at $329 \mathrm{~K}$ for $20 \mathrm{~h}$ under an argon atmosphere. When TLC (cyclohexaneAcOEt, 10:1 v/v, $\mathrm{FeCl}_{3}$ stain) showed complete consumption of (IV) $\left(R_{\mathrm{F}}=0.43\right)$ and the formation of a new spot that corresponds to $(\mathrm{V})\left(R_{\mathrm{F}}=0.23\right)$, the reaction was stopped. Finally, the suspension was filtered through compacted silica, washed with ethyl ether and the filtrate concentrated in vacuo. The resulting solid was purified by column chromatography (silica, cyclohexane/ethyl acetate up to 20:1 v/v), to give a white solid (yield $550 \mathrm{mg}, 30 \%$ ). Analysis found (calculated) for $\mathrm{C}_{28} \mathrm{H}_{38} \mathrm{O}_{6}$ (\%): C 70.6 (71.4), $\mathrm{H} 7.7$ (8.1). ${ }^{1} \mathrm{H} \mathrm{NMR} \mathrm{(500} \mathrm{MHz,} \mathrm{CDCl}_{3}$ ): $\delta$ $7.35(d d, 2 \mathrm{H}, J=7.7,2.3 \mathrm{~Hz}, \operatorname{Ar} H), 7.23(d, 2 \mathrm{H}, J=2.3 \mathrm{~Hz}$, $\operatorname{ArH}), 7.00(d, 2 \mathrm{H}, J=8.0 \mathrm{~Hz}, \operatorname{Ar} H), 4.05(t, J=6.5 \mathrm{~Hz}, 4 \mathrm{H}$, $\left.\mathrm{CH}_{2} \mathrm{O}-\right), 2.34\left(s, 6 \mathrm{H},-\mathrm{OCOCH}_{3}\right), 1.80\left(m, 4 \mathrm{H}, \mathrm{CH}_{2} \mathrm{CH}_{2} \mathrm{O}-\right)$, 1.50-1.30 [m, 12H, O $\left.\left(\mathrm{CH}_{2}\right)_{2}\left(\mathrm{CH}_{2}\right)_{3} \mathrm{CH}_{3}\right], 0.94[t, 6 \mathrm{H}, J=$ $\left.7.1 \mathrm{~Hz}, \mathrm{O}\left(\mathrm{CH}_{2}\right)_{5} \mathrm{CH}_{3}\right] ;{ }^{13} \mathrm{C} \mathrm{NMR}\left(125.7 \mathrm{MHz}, \mathrm{CDCl}_{3}\right): \delta 169.1$ $\left(-\mathrm{OCOCH}_{3}\right), 149.9,140.4,133.1,125.0,121.2,113.7$ (Ar), $69.0\left(\mathrm{OCH}_{2}\right), 31.6,29.3,25.7,22.7\left[\mathrm{OCH}_{2}\left(\mathrm{CH}_{2}\right)_{4} \mathrm{CH}_{3}\right], 20.7$ $\left(-\mathrm{OCOCH}_{3}\right), 14.1\left[\mathrm{OCH}_{2}\left(\mathrm{CH}_{2}\right)_{4} \mathrm{CH}_{3}\right]$; FT-IR diagnostic bands: $3045\left(v \mathrm{C}_{\text {aromatic }}-\mathrm{H}\right), 2958\left(v_{\mathrm{CH}_{3}}{ }^{\text {assym }}\right), 2934\left(\nu \mathrm{CH}_{2}{ }^{\text {assym }}\right), 2867$ $\left(\nu \mathrm{CH}_{3}{ }^{\mathrm{sym}}\right), 2859\left(\nu \mathrm{CH}_{2}{ }^{\mathrm{sym}}\right), 1771 \mathrm{~cm}^{-1}(\nu \mathrm{C}=\mathrm{O})$. A second set of fractions was collected and evaporated to dryness, yielding (I) as a white solid. Single crystals of (I) were grown by slow 
Table 1

Experimental details.

Crystal data

Chemical formula

$M_{\mathrm{r}}$

Crystal system, space group

Temperature (K)

$a, b, c(\AA)$

$V\left(\AA^{3}\right)$

$Z$

Radiation type

$\mu\left(\mathrm{mm}^{-1}\right)$

Crystal size (mm)

Data collection

Diffractometer

Absorption correction

$T_{\min }, T_{\max }$

No. of measured, independent and observed $[I>2 \sigma(I)]$ reflections

$R_{\text {int }}$

$(\sin \theta / \lambda)_{\max }\left(\AA^{-1}\right)$

$\mathrm{C}_{14} \mathrm{H}_{20} \mathrm{O}_{3}$

236.30

Orthorhombic, $\mathrm{Pbca}$

170

19.3847 (10), $9.0716(4)$ $30.3953(12)$

5345.0 (4)

16

Mo $K \alpha$

0.08

$0.32 \times 0.26 \times 0.18$

Oxford Diffraction Xcalibur (Eos, Gemini) CCD diffractometer

Multi-scan (CrysAlis PRO; Oxford Diffraction, 2009)

$0.95,0.98$

$18445,6210,3357$

0.058

0.683

Refinement

$R\left[F^{2}>2 \sigma\left(F^{2}\right)\right], w R\left(F^{2}\right), S$

No. of reflections

No. of parameters

No. of restraints

$\mathrm{H}$-atom treatment

$\Delta \rho_{\max }, \Delta \rho_{\min }\left(\mathrm{e} \AA^{-3}\right)$
$\left.\mathrm{O}\left(\mathrm{CH}_{2}\right)_{2}\left(\mathrm{CH}_{2}\right)_{3} \mathrm{CH}_{3}\right], 0.90\left[t, 3 \mathrm{H}, J=7.0 \mathrm{~Hz}, \mathrm{O}\left(\mathrm{CH}_{2}\right)_{5} \mathrm{CH}_{3}\right]$; ${ }^{13} \mathrm{C} \mathrm{NMR}\left(\mathrm{CDCl}_{3}, 125.7 \mathrm{MHz}\right): \delta 197.1\left(-\mathrm{COCH}_{3}\right), 150.2$, 145.6, 130.9, 121.9, 114.5, 110.7 (Ar), $69.2\left(\mathrm{OCH}_{2}\right), 31.6,29.1$, 26.5, $25.7\left[\mathrm{OCH}_{2}\left(\mathrm{CH}_{2}\right)_{4} \mathrm{CH}_{3}\right], 22.7\left(-\mathrm{COCH}_{3}\right), 14.1\left[\mathrm{OCH}_{2}-\right.$ $\left.\left(\mathrm{CH}_{2}\right)_{4} \mathrm{CH}_{3}\right]$. For a complete assignment of the ${ }^{1} \mathrm{H} \mathrm{NMR}$ and ${ }^{13} \mathrm{C}$ NMR spectra, see Results and discussion (\$3).

\subsection{Refinement}

Crystal data, data collection and structure refinement details for (I) are summarized in Table 1. All $\mathrm{H}$ atoms were originally found in difference maps, but were treated differently in the refinement. The $\mathrm{O}-\mathrm{H}$ groups were refined freely with free $U_{\text {iso }}$ values, while the $\mathrm{C}-\mathrm{H}$ groups were repositioned in their expected positions and allowed to ride, with $\mathrm{C}-\mathrm{H}=$ $0.93 \AA$ and $U_{\text {iso }}(\mathrm{H})=1.2 U_{\text {eq }}(\mathrm{C})$ for aromatic $\mathrm{H}$ atoms, $\mathrm{C}-\mathrm{H}=$ $0.97 \AA$ and $U_{\text {iso }}(\mathrm{H})=1.2 U_{\text {eq }}(\mathrm{C})$ for methylene $\mathrm{H}$ atoms, and $\mathrm{C}-\mathrm{H}=0.96 \AA$ and $U_{\text {iso }}(\mathrm{H})=1.5 U_{\text {eq }}(\mathrm{C})$ for methyl $\mathrm{H}$ atoms. The hexyl tail in one of the independent molecules appeared disordered over two positions. A split model was refined with restrained geometry and displacement parameters, and the refined occupancies were 0.691 (4) and 0.309 (4).

\section{Results and discussion}

The title compound, (I), crystallizes in the orthorhombic space group $\mathrm{Pbca}$ and the asymmetric unit consists of two independent molecules (Fig. 1), one of which is disordered (see Refinement, §2.2). Unexpectedly, these molecules do not correspond to any kind of substituted biphenyl, but to 1-(4hexyloxy-3-hydroxyphenyl)ethanone.

Once the chemical nature of (I) had been established crystallographically, further evidence was obtained from spectral data. Indeed, the IR spectrum of (I) shows the expected $\nu \mathrm{CH}_{2}$ and $\nu \mathrm{CH}_{3}$ bands in the $2850-2950 \mathrm{~cm}^{-1}$ region, a $\nu \mathrm{C}_{\text {aromatic }}-\mathrm{H}$ band at $c a 3100 \mathrm{~cm}^{-1}$ and a $\nu \mathrm{C}-\mathrm{C}_{\text {aromatic }}$ band at $c a 1600 \mathrm{~cm}^{-1}$, all of which are already present in the starting material 5-bromo-2-(hexyloxy)phenyl acetate, (IV). In agreement with the lack of an acetoxy group and the presence of a ketone moiety, the $\nu \mathrm{C}=\mathrm{O}$ band shifted from $1776 \mathrm{~cm}^{-1}$ in (IV) to $1666 \mathrm{~cm}^{-1}$ in (I), an identical value to that found in benzophenone. Compound (I) also exhibits an additional broad band at $3308 \mathrm{~cm}^{-1}$, assigned to the new phenolic $\mathrm{O}-\mathrm{H}$ group. ${ }^{1} \mathrm{H}$ NMR, ${ }^{13} \mathrm{C}$ NMR and COSY spectra are shown on

$5.79(s, 1 \mathrm{H}, \mathrm{OH}), 4.10\left(t, J=6.6 \mathrm{~Hz}, 2 \mathrm{H}, \mathrm{CH}_{2} \mathrm{O}-\right), 2.53(s, 1 \mathrm{H}$ $\left.\mathrm{CH}_{3} \mathrm{CO}-\right), 1.84\left(m, 2 \mathrm{H}, \mathrm{CH}_{2} \mathrm{CH}_{2} \mathrm{O}-\right), 1.46-1.32[m, 6 \mathrm{H}$,

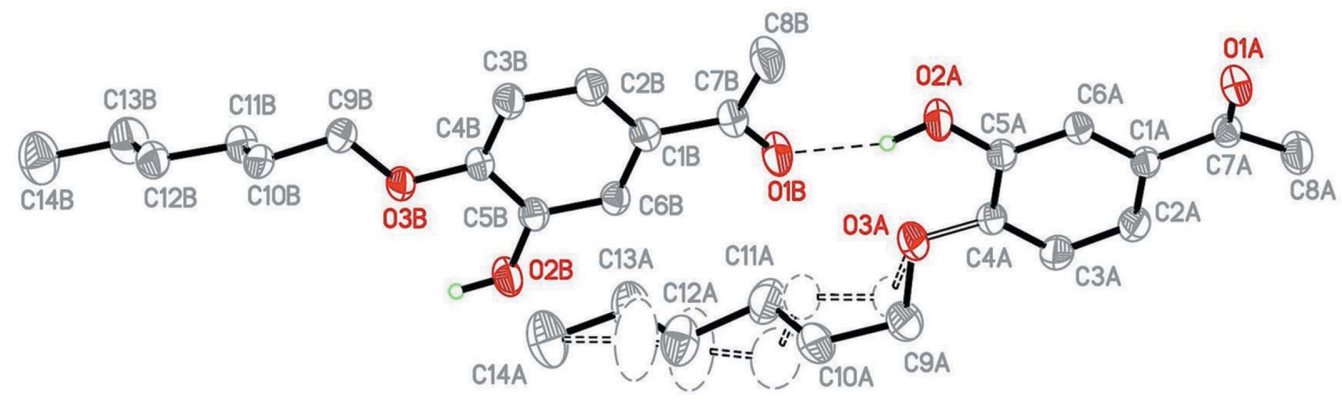

Figure 1

The molecular structure of (I), with displacement ellipsoids drawn at the $40 \%$ probability level. Single broken lines represent hydrogen bonds and double broken lines (and empty ellipsoids) correspond to the (unlabelled) minor fraction of the disordered hexyl group. 


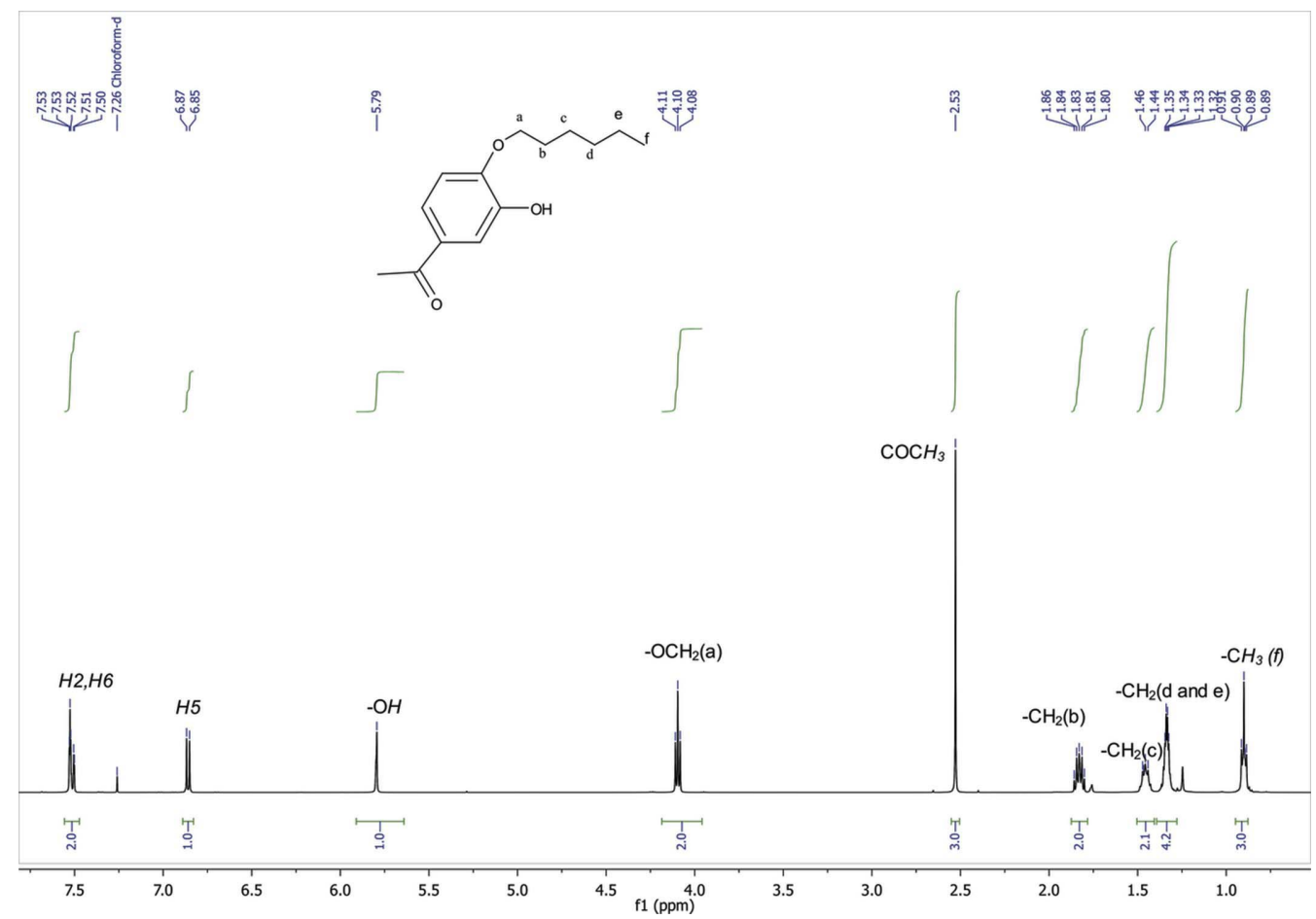

Figure 2

The assigned ${ }^{1} \mathrm{H}$ NMR spectrum of (I).

Figs. 2, 3 and 4, respectively, which also contain the assignment of each detected signal. The ${ }^{1} \mathrm{H}$ NMR spectrum of (I) shows the characteristic signals of the aromatic ring at about 7.0 p.p.m. The multiplicities of the different signals are in agreement with the substitution pattern observed and, as expected, the aromatic $\mathrm{H}-2$ atom was the more unprotected (at low fields) due to the neighbouring effect of the $\mathrm{OH}$ and ketone groups. This assignment was confirmed by the coupling constant observed, i.e. $J=2.0 \mathrm{~Hz}$, a value typical for metacoupling. The aromatic H-6 atom was found at 7.50 p.p.m. as a

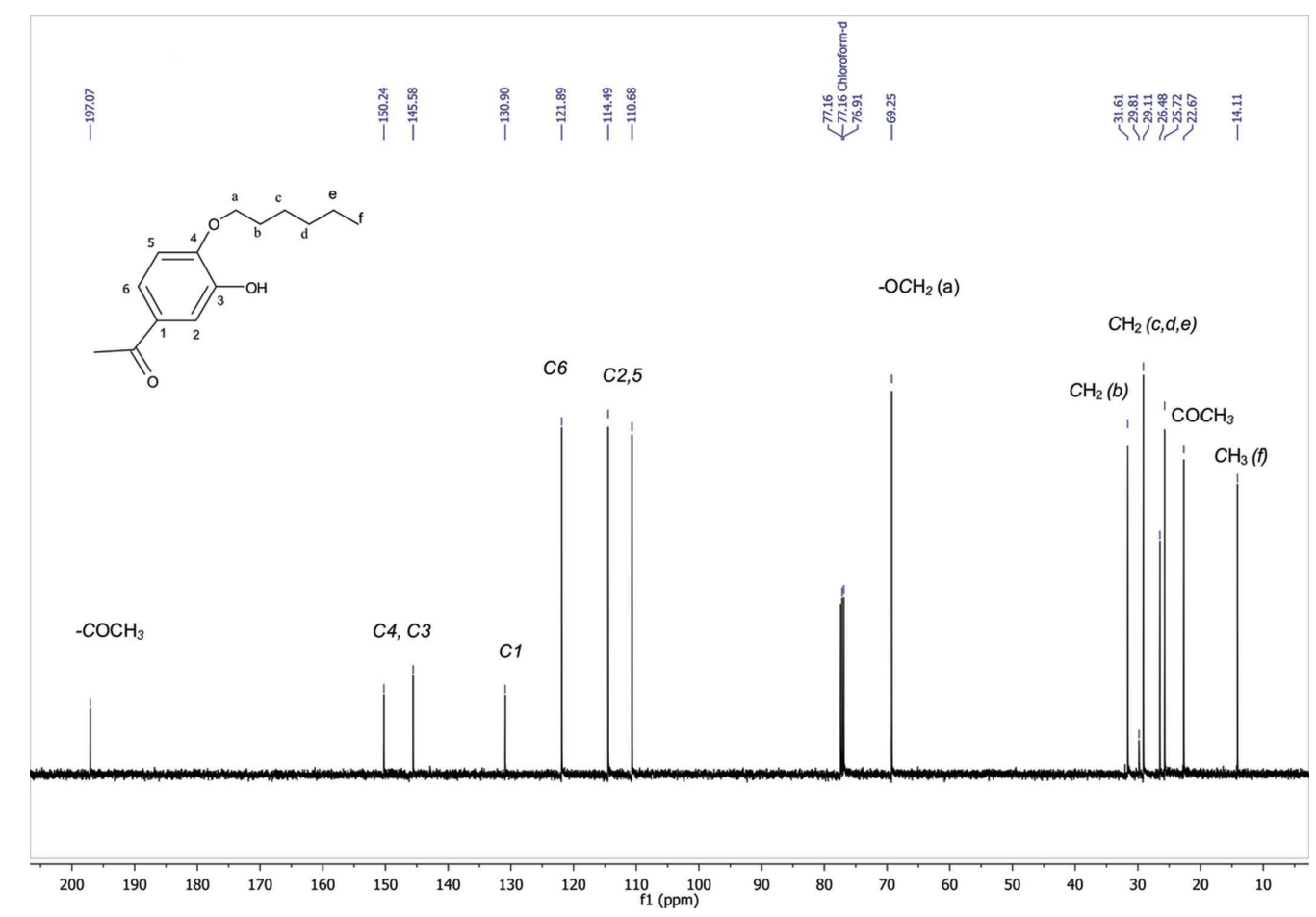

Figure 3

The assigned ${ }^{13} \mathrm{C}$ NMR spectrum of (I). 


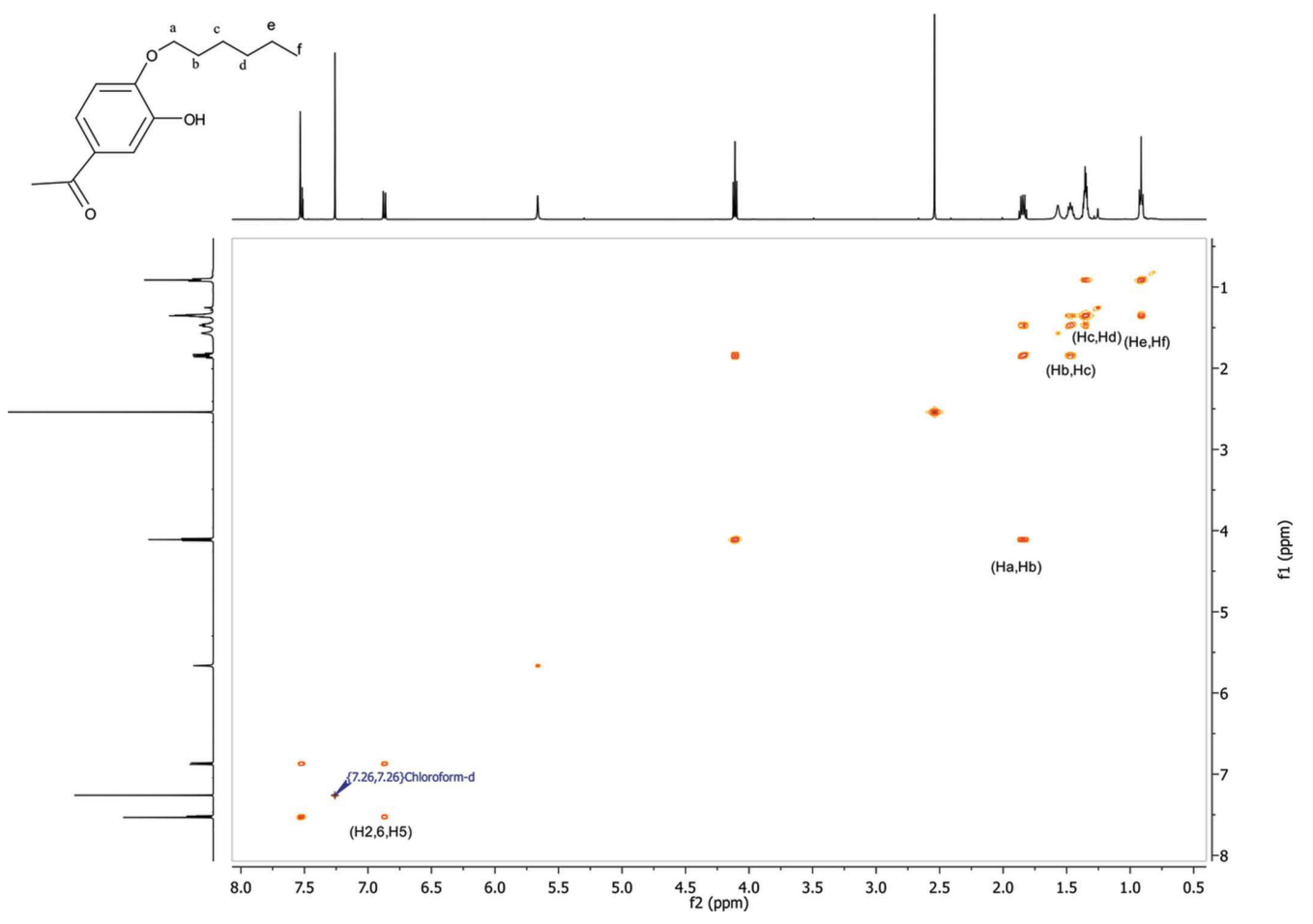

Figure 4

The COSY (correlation spectroscopy) analysis for (I).

Table 2

Hydrogen-bond geometry $\left(\AA{ }^{\circ}\right)$.

\begin{tabular}{lllll}
\hline$D-\mathrm{H} \cdots A$ & $D-\mathrm{H}$ & $\mathrm{H} \cdots A$ & $D \cdots A$ & $D-\mathrm{H} \cdots A$ \\
\hline $\mathrm{O} 2 A-\mathrm{H} 2 \mathrm{O} A \cdots \mathrm{O} 1 B$ & $0.96(3)$ & $1.83(3)$ & $2.735(2)$ & $156(3)$ \\
$\mathrm{O} 2 B-\mathrm{H} 2 \mathrm{O} B \cdots \mathrm{O} 1 A^{\mathrm{i}}$ & $0.92(3)$ & $1.89(3)$ & $2.779(2)$ & $161(3)$ \\
\hline
\end{tabular}

Symmetry code: (i) $x,-y+\frac{1}{2}, z-\frac{1}{2}$.

doublet of doublets with $J=8.3 \mathrm{~Hz}$, typical of ortho-coupling, and $J=2.0 \mathrm{~Hz}$ due to meta-coupling with $\mathrm{H}-2$. Aromatic $\mathrm{H}-5$ was found at 6.86 p.p.m. as a doublet with the same orthocoupling. Other diagnostic signals were that of the phenolic $\mathrm{H}$ atom, detected as a singlet at 5.79 p.p.m., that of the $\alpha$ methylene group of the hexyloxy tail, detected at 4.10 p.p.m. (the other signals corresponding to this hydrocarbon chain appeared in the range $1.86-0.89$ p.p.m.) and the singlet of the methyl group of the ketone group at 2.53 p.p.m. The COSY spectrum showed both the correlation between the aromatic $\mathrm{H}$ atoms and the lack of interactions for the signal at 5.79 p.p.m., as expected for the phenol $\mathrm{H}$ atom. The most distinctive signal in the ${ }^{13} \mathrm{C}$ NMR spectrum of (I) is that at 197.1 p.p.m., which corresponds to the ketone $\mathrm{C}$ atom; all other observed signals are in agreement with the proposed structure.

Since the molecular structure of (I) does not depart from expected values, the discussion of the structure will be restricted to the supramolecular architecure.

Intermolecular interactions are dominated by hydroxyethanone $\mathrm{O}-\mathrm{H} \cdots \mathrm{O}$ hydrogen bonds (Table 2) which link molecules into columnar arrays built up by the $c$-glide plane in an $\cdots A-B-A-B \cdots$ sequence along [001] (Fig. 5, left). The interactive part in the columns ( $\mathrm{O}$ atoms and $\pi$ rings) are in turn 'shielded' from external interactions by the hexyl tails

Figure 5
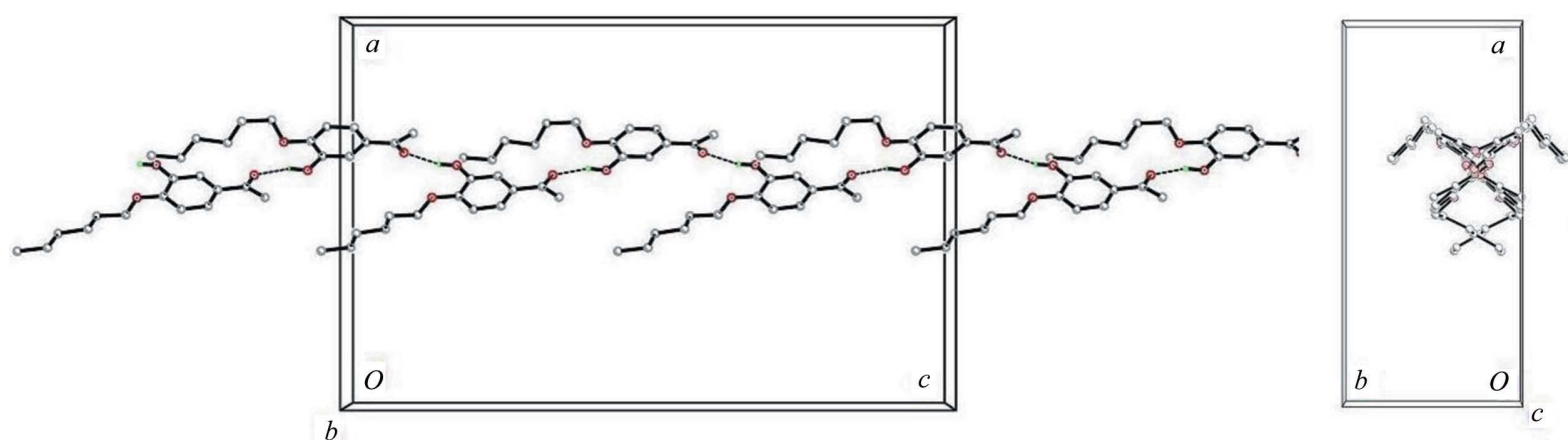

The columnar arrays in the structure of (I), showing (left) the $\cdots A-B-A-B \cdots$ sequence along [001] and (right) a single column seen in projection, showing the 'shielding' of the potentially interactive core. 


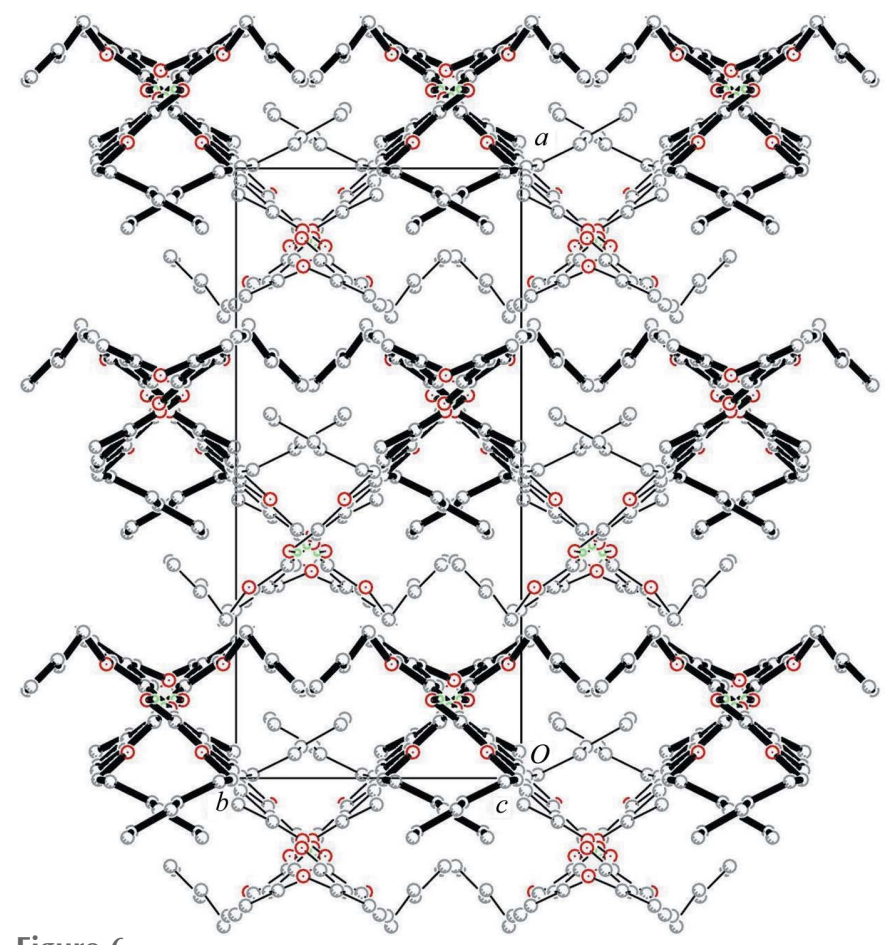

Figure 6

A packing view drawn along the column direction. Neighbouring columns are shown arbitrarily in light and dark for clarity.

wrapping the around the columns (Fig. 5, right). Thus, intercolumn interactions are attained solely through weaker van der Waals forces (Fig. 6). Irrespective of this fact, the structure appears well packed, with no room for solvent molecules and a Kitajgorodskij packing index of $0.67 \%$ (PLATON; Spek, 2009).

As is common practice when dealing with compounds containing alkyl $\mathrm{C}_{n} \mathrm{H}_{2 n+1}$ tails, we looked in the Cambridge Structural Database (CSD, Version 5.3, update of May 2015; Groom \& Allen, 2014) for other members of the series, viz. of the 1-[4-(n-yloxy)-3-hydroxyphenyl]ethanone type $(n \neq 6)$, for comparison purposes. To our surprise, we found that no further members of the family have been reported. In fact, even the parent (3-hydroxyphenyl)ethanone skeleton is rare, with only two structures including this moiety reported in the CSD (refcodes JIVREL and HALYOI; Byrn et al., 1991, 1993). However, in these cases, the (3-hydroxyphenyl)ethanone skeleton does not appear as an isolated molecule or as the core of a higher homologue, but as part of complex structures. Consequently, it is not possible to compare the $C(7)$ synthon responsible of the chain array in (I) with related structures. More frequently observed is the (2-hydroxyphenyl)ethanone skeleton, with both substitutents in neighbouring sites. This disposition, however, largely promotes an intramolecular $\mathrm{O}-$ $\mathrm{H}$. . O synthon defining an internal $R(6)$ loop, and compar- isons are again precluded. Thus, against this background, the present structure of (I) could be considered as 'novel'.

From a chemical point of view, it is well known (Matsumoto et al., 1983; Sperotto et al., 2010) that the Ni-modified Ullmann reaction involves in a first step a reduction of $\mathrm{Ni}^{2+}$ to $\mathrm{Ni}^{0}$, and it is $\mathrm{Ni}^{0}$ that reacts, in our case, via an oxidative addition of a molecule of (IV). This complex then reacts with another molecule of (IV) to give an intermediate in which nickel is oxidized to $\mathrm{Ni}^{4+}$. The last step in the formation of the biaryl product involves a reductive elimination which reconstitutes the nickel catalyst. We think that a plausible explanation for the formation of (I) could involve a cleavage of the $\mathrm{O}-\mathrm{C}$ linkage of the acetoxy group which suffers an intramolecular rearrangement to give product (I), in which the acyl group replaces the $\mathrm{Br}$ atom.

\section{Acknowledgements}

The authors acknowledge ANPCyT (project No. PME 200601113) for the purchase of the Oxford Gemini CCD diffractometer, the University of Buenos Aires (grant No. UBACyT grant 20020130100776BA) for financial support, CONICET for a postdoctoral fellowship to VEM and Dr Pablo Alborés for the collection of the X-ray diffraction data. FDC is a member of the research staff of Conicet.

\section{References}

Bushby, R. J. \& Kawata, K. (2011). Liq. Cryst. 38, 1415-1426.

Byrn, M. P., Curtis, C. J., Goldberg, I., Hsiou, Y., Khan, S. I., Sawin, P. A., Tendick, S. K. \& Strouse, C. E. (1991). J. Am. Chem. Soc. 113, 6549-6557.

Byrn, M. P., Curtis, C. J., Hsiou, Y., Khan, S. I., Sawin, P. A., Tendick, S. K., Terzis, A. \& Strouse, C. E. (1993). J. Am. Chem. Soc. 115, 9480-9497.

Groom, C. R. \& Allen, F. H. (2014). Angew. Chem. Int. Ed. 53, 662 671.

Hong, R., Hoen, R., Zhang, J. \& Lin, G.-Q. (2001). Synlett, 10, $1527-$ 1530.

Matsumoto, H., Inaba, S. \& Rieke, R. D. (1983). J. Org. Chem. 48, 840-843.

Oxford Diffraction (2009). CrysAlis PRO. Oxford Diffraction Ltd, Yarnton, Oxfordshire, England.

Pal, S. K., Setia, S., Avinash, B. S. \& Kumar, S. (2013). Liq. Cryst. 40, 1769-1816.

Sheldrick, G. M. (2008). Acta Cryst. A64, 112-122.

Sheldrick, G. M. (2015). Acta Cryst. C71, 3-8.

Spek, A. L. (2009). Acta Cryst. D65, 148-155.

Sperotto, E., van Klink, G. P. M., van Koten, G. \& de Vries, J. G. (2010). Dalton Trans. 39, 10338-10351.

Zelcer, A., Cecchi, F., Albores, P., Guillon, D., Heinrich, B., Donnio, B. \& Cukiernik, F. D. (2013). Liq. Cryst. 40, 1121-1134.

Zelcer, A., Donnio, B., Bourgogne, C., Cukiernik, F. D. \& Guillon, D. (2007). Chem. Mater. 19, 1992-2006.

Zembayashi, M., Tamao, K., Yoshida, J.-I. \& Kumada, M. (1977). Tetrahedron Lett. 47, 4089-4092. 


\section{supporting information}

Acta Cryst. (2015). C71, 1022-1027 [doi:10.1107/S2053229615019919]

\section{Crystallographic identification of an unexpected by-product in an Ullman's reaction toward biphenyls: 1-(4-hexyloxy-3-hydroxyphenyl)ethanone}

\section{Veronica E. Manzano, Ricardo Baggio and Fabio D. Cukiernik}

Computing details

Data collection: CrysAlis PRO (Oxford Diffraction, 2009); cell refinement: CrysAlis PRO (Oxford Diffraction, 2009); data reduction: CrysAlis PRO (Oxford Diffraction, 2009); program(s) used to solve structure: SHELXS97 (Sheldrick, 2008); program(s) used to refine structure: SHELXL2014 (Sheldrick, 2015); molecular graphics: SHELXTL (Sheldrick, 2008); software used to prepare material for publication: SHELXL2014 (Sheldrick, 2015) and PLATON (Spek, 2009).

1-(4-Hexyloxy-3-hydroxyphenyl)ethanone

Crystal data

$\mathrm{C}_{14} \mathrm{H}_{20} \mathrm{O}_{3}$

$M_{r}=236.30$

Orthorhombic, $\mathrm{Pbca}$

$a=19.3847$ (10) $\AA$

$b=9.0716(4) \AA$

$c=30.3953(12) \AA$

$V=5345.0(4) \AA^{3}$

$Z=16$

$F(000)=2048$

Data collection

CCD Oxford Diffraction Xcalibur (Eos, Gemini)

diffractometer

Radiation source: Enhance (Mo) X-ray Source

Detector resolution: 16.1158 pixels $\mathrm{mm}^{-1}$

thick slices scans

Absorption correction: multi-scan (CrysAlis PRO; Oxford Diffraction, 2009)

$T_{\min }=0.95, T_{\max }=0.98$

Refinement

Refinement on $F^{2}$

Least-squares matrix: full

$R\left[F^{2}>2 \sigma\left(F^{2}\right)\right]=0.067$

$w R\left(F^{2}\right)=0.189$

$S=1.02$

6210 reflections

365 parameters

23 restraints
$D_{\mathrm{x}}=1.175 \mathrm{Mg} \mathrm{m}^{-3}$

Mo $K \alpha$ radiation, $\lambda=0.71073 \AA$

Cell parameters from 2185 reflections

$\theta=3.9-26.4^{\circ}$

$\mu=0.08 \mathrm{~mm}^{-1}$

$T=170 \mathrm{~K}$

Blocks, colourless

$0.32 \times 0.26 \times 0.18 \mathrm{~mm}$

18445 measured reflections

6210 independent reflections

3357 reflections with $I>2 \sigma(I)$

$R_{\text {int }}=0.058$

$\theta_{\max }=29.0^{\circ}, \theta_{\min }=3.7^{\circ}$

$h=-18 \rightarrow 25$

$k=-12 \rightarrow 11$

$l=-39 \rightarrow 27$

Hydrogen site location: mixed

$\mathrm{H}$ atoms treated by a mixture of independent and constrained refinement

$w=1 /\left[\sigma^{2}\left(F_{\mathrm{o}}^{2}\right)+(0.0741 P)^{2}+0.6907 P\right]$

where $P=\left(F_{\mathrm{o}}^{2}+2 F_{\mathrm{c}}^{2}\right) / 3$

$(\Delta / \sigma)_{\max }<0.001$

$\Delta \rho_{\max }=0.29 \mathrm{e} \AA^{-3}$

$\Delta \rho_{\min }=-0.31$ e $\AA^{-3}$ 


\section{Special details}

Geometry. All e.s.d.'s (except the e.s.d. in the dihedral angle between two 1.s. planes) are estimated using the full covariance matrix. The cell e.s.d.'s are taken into account individually in the estimation of e.s.d.'s in distances, angles and torsion angles; correlations between e.s.d.'s in cell parameters are only used when they are defined by crystal symmetry. An approximate (isotropic) treatment of cell e.s.d.'s is used for estimating e.s.d.'s involving l.s. planes.

Fractional atomic coordinates and isotropic or equivalent isotropic displacement parameters $\left(\AA^{2}\right)$

\begin{tabular}{|c|c|c|c|c|c|}
\hline & $x$ & $y$ & $z$ & $U_{\text {iso }} * / U_{\text {eq }}$ & Occ. $(<1)$ \\
\hline O1A & $0.66050(9)$ & $0.23557(17)$ & $0.59045(5)$ & $0.0446(4)$ & \\
\hline $\mathrm{C} 1 \mathrm{~A}$ & $0.68678(11)$ & $0.3851(2)$ & $0.52954(6)$ & $0.0346(5)$ & \\
\hline $\mathrm{C} 2 \mathrm{~A}$ & $0.72377(12)$ & 0.5033 & $0.51287(7)$ & $0.0459(6)$ & \\
\hline $\mathrm{H} 2 \mathrm{~A}$ & 0.7473 & 0.5660 & 0.5319 & $0.055^{*}$ & \\
\hline $\mathrm{C} 3 \mathrm{~A}$ & $0.72574(13)$ & $0.5281(3)$ & $0.46765(7)$ & $0.0523(7)$ & \\
\hline $\mathrm{H} 3 \mathrm{~A}$ & 0.7518 & 0.6056 & 0.4565 & $0.063^{*}$ & \\
\hline $\mathrm{C} 4 \mathrm{~A}$ & $0.68947(11)$ & $0.4392(3)$ & $0.43964(7)$ & $0.0398(5)$ & \\
\hline $\mathrm{C} 5 \mathrm{~A}$ & 0.65089 (11) & $0.3203(2)$ & $0.45608(7)$ & $0.0348(5)$ & \\
\hline C6A & $0.65032(11)$ & $0.2950(2)$ & $0.50085(7)$ & $0.0338(5)$ & \\
\hline H6A & 0.6251 & 0.2162 & 0.5120 & $0.041^{*}$ & \\
\hline C7A & $0.68423(11)$ & $0.3532(3)$ & $0.57753(7)$ & $0.0370(5)$ & \\
\hline $\mathrm{C} 8 \mathrm{~A}$ & $0.70922(14)$ & $0.4665(3)$ & $0.60948(7)$ & $0.0559(7)$ & \\
\hline H8AA & 0.7034 & 0.4304 & 0.6389 & $0.084 *$ & \\
\hline H8AB & 0.6832 & 0.5556 & 0.6058 & $0.084^{*}$ & \\
\hline $\mathrm{H} 8 \mathrm{AC}$ & 0.7572 & 0.4861 & 0.6042 & $0.084 *$ & \\
\hline $\mathrm{O} 2 \mathrm{~A}$ & $0.61431(9)$ & $0.23021(17)$ & $0.42929(5)$ & $0.0474(4)$ & \\
\hline $\mathrm{H} 2 \mathrm{OA}$ & $0.6184(15)$ & $0.253(3)$ & $0.3985(10)$ & $0.078(9)^{*}$ & \\
\hline $\mathrm{O} 3 \mathrm{~A}$ & $0.68699(9)$ & $0.45456(19)$ & $0.39488(5)$ & $0.0529(5)$ & $0.691(4)$ \\
\hline C9A & $0.7402(3)$ & $0.5463(7)$ & $0.37586(14)$ & $0.082(3)$ & $0.691(4)$ \\
\hline H9AA & 0.7850 & 0.5150 & 0.3866 & $0.099 *$ & $0.691(4)$ \\
\hline H9AB & 0.7331 & 0.6479 & 0.3847 & $0.099 *$ & $0.691(4)$ \\
\hline C10A & $0.7384(3)$ & $0.5354(7)$ & $0.32708(13)$ & 0.0944 (19) & $0.691(4)$ \\
\hline $\mathrm{H} 10 \mathrm{~A}$ & 0.7827 & 0.5671 & 0.3156 & $0.113^{*}$ & $0.691(4)$ \\
\hline H10B & 0.7322 & 0.4328 & 0.3190 & $0.113^{*}$ & $0.691(4)$ \\
\hline C11A & $0.6841(3)$ & $0.6226(8)$ & $0.30612(15)$ & $0.0990(19)$ & $0.691(4)$ \\
\hline H11A & 0.6846 & 0.7217 & 0.3182 & $0.119^{*}$ & $0.691(4)$ \\
\hline H11B & 0.6396 & 0.5791 & 0.3128 & $0.119^{*}$ & $0.691(4)$ \\
\hline $\mathrm{C} 12 \mathrm{~A}$ & $0.6936(3)$ & $0.6308(5)$ & $0.25457(14)$ & $0.0882(15)$ & 0.691 (4) \\
\hline $\mathrm{H} 12 \mathrm{~A}$ & 0.7399 & 0.6651 & 0.2480 & $0.106^{*}$ & $0.691(4)$ \\
\hline H12B & 0.6886 & 0.5327 & 0.2423 & $0.106^{*}$ & $0.691(4)$ \\
\hline C13A & $0.6455(3)$ & $0.7257(6)$ & $0.23440(13)$ & $0.0829(16)$ & $0.691(4)$ \\
\hline $\mathrm{H} 13 \mathrm{~A}$ & 0.6538 & 0.8260 & 0.2441 & $0.099 *$ & $0.691(4)$ \\
\hline H13B & 0.5993 & 0.6981 & 0.2435 & $0.099 *$ & $0.691(4)$ \\
\hline C14A & $0.6503(2)$ & $0.7191(4)$ & $0.18381(9)$ & $0.0906(11)$ & $0.691(4)$ \\
\hline $\mathrm{H} 14 \mathrm{~A}$ & 0.6161 & 0.7830 & 0.1712 & $0.136^{*}$ & $0.691(4)$ \\
\hline H14B & 0.6423 & 0.6198 & 0.1741 & $0.136^{*}$ & $0.691(4)$ \\
\hline $\mathrm{H} 14 \mathrm{C}$ & 0.6954 & 0.7503 & 0.1746 & $0.136^{*}$ & $0.691(4)$ \\
\hline $\mathrm{O}^{\prime}$ & $0.68699(9)$ & $0.45456(19)$ & $0.39488(5)$ & $0.0529(5)$ & 0.309 (4) \\
\hline$C 9^{\prime}$ & $0.7129(7)$ & $0.5850(12)$ & $0.3735(2)$ & $0.065(4)$ & $0.309(4)$ \\
\hline
\end{tabular}




\begin{tabular}{|c|c|c|c|c|c|}
\hline H9C & 0.7629 & 0.5854 & 0.3747 & $0.078^{*}$ & 0.309 (4) \\
\hline H9D & 0.6962 & 0.6717 & 0.3888 & $0.078^{*}$ & $0.309(4)$ \\
\hline $\mathrm{C} 10^{\prime}$ & $0.6901(5)$ & $0.5904(14)$ & $0.3267(2)$ & $0.065(3)$ & 0.309 (4) \\
\hline $\mathrm{H} 10 \mathrm{C}$ & 0.6411 & 0.6126 & 0.3256 & $0.078^{*}$ & $0.309(4)$ \\
\hline H10D & 0.6971 & 0.4946 & 0.3133 & $0.078^{*}$ & 0.309 (4) \\
\hline $\mathrm{C} 11^{\prime}$ & $0.7281(6)$ & $0.7021(13)$ & $0.3016(2)$ & $0.099(2)$ & $0.309(4)$ \\
\hline $\mathrm{H} 11 \mathrm{C}$ & 0.7372 & 0.7855 & 0.3207 & $0.119^{*}$ & 0.309 (4) \\
\hline H11D & 0.7723 & 0.6610 & 0.2930 & $0.119 *$ & 0.309 (4) \\
\hline $\mathrm{C} 12^{\prime}$ & $0.6905(6)$ & $0.7593(9)$ & $0.2593(2)$ & 0.0888 (16) & $0.309(4)$ \\
\hline $\mathrm{H} 12 \mathrm{C}$ & 0.6449 & 0.7937 & 0.2675 & $0.107^{*}$ & $0.309(4)$ \\
\hline H12D & 0.7158 & 0.8431 & 0.2478 & $0.107^{*}$ & 0.309 (4) \\
\hline C13' & $0.6837(8)$ & $0.6543(13)$ & $0.2259(2)$ & $0.128(7)$ & $0.309(4)$ \\
\hline $\mathrm{H} 13 \mathrm{C}$ & 0.6557 & 0.5732 & 0.2366 & $0.153 *$ & $0.309(4)$ \\
\hline H13D & 0.7289 & 0.6154 & 0.2187 & $0.153^{*}$ & 0.309 (4) \\
\hline $\mathrm{C} 14^{\prime}$ & $0.6503(2)$ & $0.7191(4)$ & $0.18381(9)$ & 0.0906 (11) & 0.309 (4) \\
\hline H14D & 0.6466 & 0.6434 & 0.1619 & $0.136^{*}$ & $0.309(4)$ \\
\hline $\mathrm{H} 14 \mathrm{E}$ & 0.6051 & 0.7559 & 0.1907 & $0.136^{*}$ & 0.309 (4) \\
\hline $\mathrm{H} 14 \mathrm{~F}$ & 0.6784 & 0.7980 & 0.1728 & $0.136^{*}$ & $0.309(4)$ \\
\hline O1B & $0.60177(9)$ & $0.23252(19)$ & $0.33965(5)$ & $0.0522(5)$ & \\
\hline C1B & $0.56349(11)$ & $0.1185(2)$ & $0.27495(7)$ & $0.0378(5)$ & \\
\hline $\mathrm{C} 2 \mathrm{~B}$ & $0.52063(13)$ & 0.0158 & $0.25549(8)$ & $0.0479(6)$ & \\
\hline H2B & 0.4972 & -0.0517 & 0.2730 & $0.057^{*}$ & \\
\hline $\mathrm{C} 3 \mathrm{~B}$ & $0.51213(13)$ & 0.0121 & $0.21008(7)$ & $0.0457(6)$ & \\
\hline H3B & 0.4829 & -0.0571 & 0.1974 & $0.055^{*}$ & \\
\hline C4B & $0.54704(11)$ & $0.1109(2)$ & $0.18399(7)$ & $0.0361(5)$ & \\
\hline $\mathrm{C} 5 \mathrm{~B}$ & $0.59232(11)$ & $0.2134(2)$ & $0.20315(7)$ & $0.0353(5)$ & \\
\hline C6B & $0.59926(11)$ & $0.2174(2)$ & $0.24814(7)$ & $0.0358(5)$ & \\
\hline H6B & 0.6282 & 0.2870 & 0.2609 & $0.043 *$ & \\
\hline C7B & $0.57128(12)$ & $0.1276(3)$ & $0.32316(7)$ & $0.0416(6)$ & \\
\hline C8B & $0.54339(15)$ & $0.0076(3)$ & $0.35173(8)$ & $0.0631(8)$ & \\
\hline H8BA & 0.5577 & 0.0238 & 0.3816 & $0.095 *$ & \\
\hline H8BB & 0.5606 & -0.0858 & 0.3418 & $0.095^{*}$ & \\
\hline H8BC & 0.4939 & 0.0076 & 0.3502 & $0.095^{*}$ & \\
\hline $\mathrm{O} 2 \mathrm{~B}$ & $0.62791(9)$ & $0.31252(18)$ & $0.17830(5)$ & $0.0486(5)$ & \\
\hline $\mathrm{H} 2 \mathrm{OB}$ & $0.6302(15)$ & $0.282(3)$ & $0.1493(10)$ & $0.074(9)^{*}$ & \\
\hline O3B & $0.54257(8)$ & $0.11987(17)$ & 0.13942 (4) & $0.0410(4)$ & \\
\hline C9B & $0.49771(12)$ & $0.0171(3)$ & $0.11721(7)$ & $0.0442(6)$ & \\
\hline H9BA & 0.4519 & 0.0206 & 0.1301 & $0.053^{*}$ & \\
\hline H9BB & 0.5154 & -0.0824 & 0.1204 & $0.053^{*}$ & \\
\hline C10B & $0.49432(12)$ & 0.0580 & $0.06956(7)$ & $0.0430(6)$ & \\
\hline $\mathrm{H} 10 \mathrm{E}$ & 0.4692 & -0.0182 & 0.0539 & $0.052 *$ & \\
\hline $\mathrm{H} 10 \mathrm{~F}$ & 0.5409 & 0.0601 & 0.0578 & $0.052 *$ & \\
\hline C11B & $0.46042(13)$ & 0.2049 & $0.06046(7)$ & $0.0482(6)$ & \\
\hline $\mathrm{H} 11 \mathrm{E}$ & 0.4895 & 0.2835 & 0.0717 & $0.058 *$ & \\
\hline $\mathrm{H} 11 \mathrm{~F}$ & 0.4165 & 0.2095 & 0.0757 & $0.058^{*}$ & \\
\hline C12B & $0.44862(13)$ & $0.2275(3)$ & $0.01119(7)$ & $0.0488(6)$ & \\
\hline $\mathrm{H} 12 \mathrm{E}$ & 0.4930 & 0.2265 & -0.0035 & $0.059 *$ & \\
\hline $\mathrm{H} 12 \mathrm{~F}$ & 0.4222 & 0.1446 & 0.0001 & $0.059 *$ & \\
\hline
\end{tabular}




\begin{tabular}{lllll} 
C13B & $0.41190(15)$ & $0.3665(3)$ & $-0.00099(9)$ & $0.0654(8)$ \\
H13E & 0.4380 & 0.4504 & 0.0098 & $0.078^{*}$ \\
H13F & 0.3670 & 0.3681 & 0.0131 & $0.078^{*}$ \\
C14B & $0.40268(18)$ & $0.3804(4)$ & $-0.05076(9)$ & $0.0767(9)$ \\
H14G & 0.3800 & 0.4717 & -0.0574 & $0.115^{*}$ \\
H14H & 0.3752 & 0.2997 & -0.0613 & $0.115^{*}$ \\
H14I & 0.4470 & 0.3784 & -0.0648 & $0.115^{*}$ \\
\hline
\end{tabular}

Atomic displacement parameters $\left(\AA^{2}\right)$

\begin{tabular}{|c|c|c|c|c|c|c|}
\hline & $U^{11}$ & $U^{22}$ & $U^{33}$ & $U^{12}$ & $U^{13}$ & $U^{23}$ \\
\hline O1A & $0.0620(11)$ & $0.0419(9)$ & $0.0300(7)$ & $0.0026(8)$ & $-0.0001(8)$ & $0.0012(7)$ \\
\hline $\mathrm{C} 1 \mathrm{~A}$ & $0.0330(11)$ & $0.0417(12)$ & $0.0289(10)$ & $0.0050(10)$ & $-0.0012(10)$ & $-0.0020(10)$ \\
\hline $\mathrm{C} 2 \mathrm{~A}$ & 0.0444 (13) & $0.0527(14)$ & $0.0406(12)$ & $-0.0118(11)$ & -0.0068 & $-0.0009(12)$ \\
\hline $\mathrm{C} 3 \mathrm{~A}$ & $0.0468(14)$ & $0.0654(16)$ & 0.0447 (13) & $-0.0223(13)$ & $-0.0028(12)$ & $0.0127(13)$ \\
\hline $\mathrm{C} 4 \mathrm{~A}$ & $0.0370(12)$ & $0.0521(14)$ & $0.0304(11)$ & $-0.0013(10)$ & $-0.0028(10)$ & $0.0051(11)$ \\
\hline $\mathrm{C} 5 \mathrm{~A}$ & $0.0343(12)$ & $0.0382(12)$ & $0.0319(10)$ & $0.0024(9)$ & $-0.0034(10)$ & $-0.0019(10)$ \\
\hline C6A & $0.0366(12)$ & $0.0335(11)$ & $0.0313(10)$ & $0.0025(9)$ & $0.0008(10)$ & $0.0014(10)$ \\
\hline C7A & $0.0345(12)$ & $0.0428(13)$ & $0.0336(11)$ & $0.0068(10)$ & $-0.0021(10)$ & $-0.0014(11)$ \\
\hline $\mathrm{C} 8 \mathrm{~A}$ & $0.0708(18)$ & $0.0616(17)$ & $0.0354(12)$ & $-0.0131(14)$ & $-0.0033(13)$ & $-0.0061(13)$ \\
\hline $\mathrm{O} 2 \mathrm{~A}$ & $0.0681(12)$ & $0.0454(9)$ & $0.0286(8)$ & $-0.0104(8)$ & $-0.0061(8)$ & $-0.0008(8)$ \\
\hline $\mathrm{O} 3 \mathrm{~A}$ & $0.0593(11)$ & $0.0687(12)$ & $0.0307(8)$ & $-0.0116(9)$ & $0.0007(8)$ & $0.0101(8)$ \\
\hline C9A & $0.086(5)$ & $0.115(6)$ & $0.045(3)$ & $-0.033(4)$ & $0.003(3)$ & $0.028(3)$ \\
\hline C10A & $0.081(4)$ & $0.154(6)$ & $0.048(2)$ & $-0.019(4)$ & $0.004(3)$ & 0.033 \\
\hline C11A & 0.115 & $0.120(5)$ & $0.062(3)$ & $-0.045(3)$ & -0.029 & $0.017(3)$ \\
\hline $\mathrm{C} 12 \mathrm{~A}$ & $0.129(4)$ & $0.063(2)$ & $0.073(3)$ & -0.019 (3) & -0.030 & $0.013(3)$ \\
\hline C13A & $0.104(4)$ & $0.092(4)$ & $0.052(3)$ & $0.001(3)$ & $-0.002(3)$ & -0.001 \\
\hline C14A & $0.123(3)$ & 0.094 (3) & $0.0552(18)$ & $0.009(2)$ & $0.0003(19)$ & 0.0209 (19) \\
\hline O3' & $0.0593(11)$ & $0.0687(12)$ & $0.0307(8)$ & $-0.0116(9)$ & $0.0007(8)$ & $0.0101(8)$ \\
\hline $\mathrm{C} 9^{\prime}$ & $0.075(10)$ & $0.064(7)$ & $0.056(7)$ & $-0.018(7)$ & $0.014(6)$ & $0.022(6)$ \\
\hline $\mathrm{C} 10^{\prime}$ & $0.039(5)$ & $0.121(10)$ & $0.035(5)$ & $-0.008(6)$ & $-0.015(5)$ & $0.020(6)$ \\
\hline $\mathrm{C} 11^{\prime}$ & $0.114(5)$ & $0.120(5)$ & $0.062(3)$ & $-0.046(4)$ & -0.028 & 0.018 \\
\hline $\mathrm{C} 12^{\prime}$ & $0.129(4)$ & $0.063(3)$ & $0.074(3)$ & -0.019 & -0.030 & $0.013(3)$ \\
\hline C13' & $0.147(15)$ & 0.188 (19) & $0.048(6)$ & 0.047 (13) & $0.017(9)$ & $-0.008(9)$ \\
\hline C14' & $0.123(3)$ & $0.094(3)$ & $0.0552(18)$ & $0.009(2)$ & $0.0003(19)$ & $0.0209(19)$ \\
\hline O1B & $0.0753(12)$ & $0.0512(10)$ & $0.0300(8)$ & $-0.0076(9)$ & $-0.0045(8)$ & $-0.0008(8)$ \\
\hline $\mathrm{C} 1 \mathrm{~B}$ & $0.0417(13)$ & $0.0400(12)$ & $0.0316(11)$ & $0.0018(10)$ & $0.0017(10)$ & $-0.0007(10)$ \\
\hline $\mathrm{C} 2 \mathrm{~B}$ & $0.0550(15)$ & $0.0503(14)$ & $0.0383(12)$ & $-0.0120(12)$ & $0.0020(12)$ & $0.0017(12)$ \\
\hline $\mathrm{C} 3 \mathrm{~B}$ & $0.0505(14)$ & $0.0506(14)$ & $0.0362(12)$ & $-0.0122(11)$ & $-0.0018(12)$ & $-0.0043(12)$ \\
\hline $\mathrm{C} 4 \mathrm{~B}$ & $0.0390(12)$ & $0.0403(12)$ & $0.0290(10)$ & $0.0003(10)$ & $0.0002(10)$ & $-0.0027(10)$ \\
\hline $\mathrm{C} 5 \mathrm{~B}$ & $0.0399(12)$ & $0.0324(11)$ & $0.0337(11)$ & $0.0012(9)$ & $0.0002(10)$ & $-0.0029(10)$ \\
\hline $\mathrm{C} 6 \mathrm{~B}$ & $0.0381(12)$ & $0.0364(11)$ & $0.0330(11)$ & $-0.0010(9)$ & $-0.0028(10)$ & $-0.0063(10)$ \\
\hline C7B & $0.0494(14)$ & $0.0414(13)$ & $0.0339(11)$ & $0.0045(11)$ & $0.0003(11)$ & $0.0016(11)$ \\
\hline $\mathrm{C} 8 \mathrm{~B}$ & $0.088(2)$ & $0.0647(18)$ & $0.0368(12)$ & $-0.0158(15)$ & $0.0003(14)$ & $0.0072(13)$ \\
\hline $\mathrm{O} 2 \mathrm{~B}$ & $0.0676(12)$ & $0.0491(10)$ & $0.0291(8)$ & $-0.0192(8)$ & $0.0032(8)$ & $-0.0042(8)$ \\
\hline O3B & $0.0461(9)$ & $0.0476(9)$ & $0.0292(7)$ & $-0.0124(7)$ & $-0.0015(7)$ & $-0.0046(7)$ \\
\hline C9B & $0.0422(13)$ & $0.0512(14)$ & $0.0393(12)$ & $-0.0109(11)$ & $-0.0023(11)$ & $-0.0082(12)$ \\
\hline C10B & $0.0402(13)$ & $0.0542(14)$ & $0.0346(11)$ & $-0.0050(11)$ & $-0.0027(11)$ & $-0.0107(11)$ \\
\hline
\end{tabular}




\begin{tabular}{lllllll} 
C11B & $0.0485(15)$ & $0.0583(16)$ & $0.0378(12)$ & $-0.0018(12)$ & $-0.0008(12)$ & $-0.0098(12)$ \\
C12B & $0.0482(15)$ & $0.0570(15)$ & $0.0413(13)$ & $0.0029(12)$ & $0.0001(12)$ & $-0.0064(12)$ \\
C13B & $0.072(2)$ & $0.0632(19)$ & $0.0611(17)$ & $0.0143(15)$ & $-0.0031(16)$ & $-0.0058(15)$ \\
C14B & $0.094(2)$ & $0.079(2)$ & $0.0569(17)$ & $0.0228(18)$ & $-0.0088(17)$ & $0.0122(17)$ \\
\hline
\end{tabular}

Geometric parameters $\left(A,{ }^{\circ}\right)$

\begin{tabular}{|c|c|c|c|}
\hline $\mathrm{O} 1 \mathrm{~A}-\mathrm{C} 7 \mathrm{~A}$ & $1.227(3)$ & C11'-H11D & 0.9700 \\
\hline $\mathrm{C} 1 \mathrm{~A}-\mathrm{C} 2 \mathrm{~A}$ & $1.386(3)$ & $\mathrm{C} 12^{\prime}-\mathrm{C} 13^{\prime}$ & $1.398(7)$ \\
\hline $\mathrm{C} 1 \mathrm{~A}-\mathrm{C} 6 \mathrm{~A}$ & $1.389(3)$ & $\mathrm{C} 12^{\prime}-\mathrm{H} 12 \mathrm{C}$ & 0.9700 \\
\hline $\mathrm{C} 1 \mathrm{~A}-\mathrm{C} 7 \mathrm{~A}$ & $1.488(3)$ & $\mathrm{C} 12^{\prime}-\mathrm{H} 12 \mathrm{D}$ & 0.9700 \\
\hline $\mathrm{C} 2 \mathrm{~A}-\mathrm{C} 3 \mathrm{~A}$ & $1.393(3)$ & $\mathrm{C} 13^{\prime}-\mathrm{C} 14^{\prime}$ & $1.551(6)$ \\
\hline $\mathrm{C} 2 \mathrm{~A}-\mathrm{H} 2 \mathrm{~A}$ & 0.9300 & $\mathrm{C} 13^{\prime}-\mathrm{H} 13 \mathrm{C}$ & 0.9700 \\
\hline $\mathrm{C} 3 \mathrm{~A}-\mathrm{C} 4 \mathrm{~A}$ & $1.368(3)$ & $\mathrm{C} 13^{\prime}-\mathrm{H} 13 \mathrm{D}$ & 0.9700 \\
\hline $\mathrm{C} 3 \mathrm{~A}-\mathrm{H} 3 \mathrm{~A}$ & 0.9300 & $\mathrm{C} 14^{\prime}-\mathrm{H} 14 \mathrm{D}$ & 0.9600 \\
\hline $\mathrm{C} 4 \mathrm{~A}-\mathrm{O} 3^{\prime}$ & $1.368(2)$ & $\mathrm{C} 14^{\prime}-\mathrm{H} 14 \mathrm{E}$ & 0.9600 \\
\hline $\mathrm{C} 4 \mathrm{~A}-\mathrm{O} 3 \mathrm{~A}$ & $1.368(2)$ & $\mathrm{C} 14^{\prime}-\mathrm{H} 14 \mathrm{~F}$ & 0.9600 \\
\hline $\mathrm{C} 4 \mathrm{~A}-\mathrm{C} 5 \mathrm{~A}$ & $1.405(3)$ & $\mathrm{O} 1 \mathrm{~B}-\mathrm{C} 7 \mathrm{~B}$ & $1.228(3)$ \\
\hline $\mathrm{C} 5 \mathrm{~A}-\mathrm{O} 2 \mathrm{~A}$ & $1.354(2)$ & $\mathrm{C} 1 \mathrm{~B}-\mathrm{C} 2 \mathrm{~B}$ & $1.381(3)$ \\
\hline $\mathrm{C} 5 \mathrm{~A}-\mathrm{C} 6 \mathrm{~A}$ & $1.380(3)$ & $\mathrm{C} 1 \mathrm{~B}-\mathrm{C} 6 \mathrm{~B}$ & $1.396(3)$ \\
\hline $\mathrm{C} 6 \mathrm{~A}-\mathrm{H} 6 \mathrm{~A}$ & 0.9300 & $\mathrm{C} 1 \mathrm{~B}-\mathrm{C} 7 \mathrm{~B}$ & $1.475(3)$ \\
\hline $\mathrm{C} 7 \mathrm{~A}-\mathrm{C} 8 \mathrm{~A}$ & $1.494(3)$ & $\mathrm{C} 2 \mathrm{~B}-\mathrm{C} 3 \mathrm{~B}$ & $1.390(3)$ \\
\hline $\mathrm{C} 8 \mathrm{~A}-\mathrm{H} 8 \mathrm{AA}$ & 0.9600 & $\mathrm{C} 2 \mathrm{~B}-\mathrm{H} 2 \mathrm{~B}$ & 0.9300 \\
\hline $\mathrm{C} 8 \mathrm{~A}-\mathrm{H} 8 \mathrm{AB}$ & 0.9600 & $\mathrm{C} 3 \mathrm{~B}-\mathrm{C} 4 \mathrm{~B}$ & $1.375(3)$ \\
\hline $\mathrm{C} 8 \mathrm{~A}-\mathrm{H} 8 \mathrm{AC}$ & 0.9600 & $\mathrm{C} 3 \mathrm{~B}-\mathrm{H} 3 \mathrm{~B}$ & 0.9300 \\
\hline $\mathrm{O} 2 \mathrm{~A}-\mathrm{H} 2 \mathrm{OA}$ & $0.96(3)$ & $\mathrm{C} 4 \mathrm{~B}-\mathrm{O} 3 \mathrm{~B}$ & $1.360(2)$ \\
\hline $\mathrm{O} 3 \mathrm{~A}-\mathrm{C} 9 \mathrm{~A}$ & $1.445(4)$ & $\mathrm{C} 4 \mathrm{~B}-\mathrm{C} 5 \mathrm{~B}$ & $1.406(3)$ \\
\hline $\mathrm{C} 9 \mathrm{~A}-\mathrm{C} 10 \mathrm{~A}$ & $1.486(5)$ & $\mathrm{C} 5 \mathrm{~B}-\mathrm{O} 2 \mathrm{~B}$ & $1.362(3)$ \\
\hline C9A-H9AA & 0.9700 & $\mathrm{C} 5 \mathrm{~B}-\mathrm{C} 6 \mathrm{~B}$ & $1.374(3)$ \\
\hline C9A-H9AB & 0.9700 & $\mathrm{C} 6 \mathrm{~B}-\mathrm{H} 6 \mathrm{~B}$ & 0.9300 \\
\hline $\mathrm{C} 10 \mathrm{~A}-\mathrm{C} 11 \mathrm{~A}$ & $1.463(7)$ & $\mathrm{C} 7 \mathrm{~B}-\mathrm{C} 8 \mathrm{~B}$ & $1.494(3)$ \\
\hline $\mathrm{C} 10 \mathrm{~A}-\mathrm{H} 10 \mathrm{~A}$ & 0.9700 & $\mathrm{C} 8 \mathrm{~B}-\mathrm{H} 8 \mathrm{BA}$ & 0.9600 \\
\hline $\mathrm{C} 10 \mathrm{~A}-\mathrm{H} 10 \mathrm{~B}$ & 0.9700 & $\mathrm{C} 8 \mathrm{~B}-\mathrm{H} 8 \mathrm{BB}$ & 0.9600 \\
\hline $\mathrm{C} 11 \mathrm{~A}-\mathrm{C} 12 \mathrm{~A}$ & $1.580(6)$ & $\mathrm{C} 8 \mathrm{~B}-\mathrm{H} 8 \mathrm{BC}$ & 0.9600 \\
\hline $\mathrm{C} 11 \mathrm{~A}-\mathrm{H} 11 \mathrm{~A}$ & 0.9700 & $\mathrm{O} 2 \mathrm{~B}-\mathrm{H} 2 \mathrm{OB}$ & $0.92(3)$ \\
\hline $\mathrm{C} 11 \mathrm{~A}-\mathrm{H} 11 \mathrm{~B}$ & 0.9700 & $\mathrm{O} 3 \mathrm{~B}-\mathrm{C} 9 \mathrm{~B}$ & $1.443(2)$ \\
\hline $\mathrm{C} 12 \mathrm{~A}-\mathrm{C} 13 \mathrm{~A}$ & $1.409(6)$ & $\mathrm{C} 9 \mathrm{~B}-\mathrm{C} 10 \mathrm{~B}$ & $1.496(3)$ \\
\hline $\mathrm{C} 12 \mathrm{~A}-\mathrm{H} 12 \mathrm{~A}$ & 0.9700 & C9B-H9BA & 0.9700 \\
\hline $\mathrm{C} 12 \mathrm{~A}-\mathrm{H} 12 \mathrm{~B}$ & 0.9700 & $\mathrm{C} 9 \mathrm{~B}-\mathrm{H} 9 \mathrm{BB}$ & 0.9700 \\
\hline $\mathrm{C} 13 \mathrm{~A}-\mathrm{C} 14 \mathrm{~A}$ & $1.542(4)$ & $\mathrm{C} 10 \mathrm{~B}-\mathrm{C} 11 \mathrm{~B}$ & $1.511(3)$ \\
\hline $\mathrm{C} 13 \mathrm{~A}-\mathrm{H} 13 \mathrm{~A}$ & 0.9700 & $\mathrm{C} 10 \mathrm{~B}-\mathrm{H} 10 \mathrm{E}$ & 0.9700 \\
\hline $\mathrm{C} 13 \mathrm{~A}-\mathrm{H} 13 \mathrm{~B}$ & 0.9700 & $\mathrm{C} 10 \mathrm{~B}-\mathrm{H} 10 \mathrm{~F}$ & 0.9700 \\
\hline $\mathrm{C} 14 \mathrm{~A}-\mathrm{H} 14 \mathrm{~A}$ & 0.9600 & $\mathrm{C} 11 \mathrm{~B}-\mathrm{C} 12 \mathrm{~B}$ & $1.529(3)$ \\
\hline $\mathrm{C} 14 \mathrm{~A}-\mathrm{H} 14 \mathrm{~B}$ & 0.9600 & C11B-H11E & 0.9700 \\
\hline $\mathrm{C} 14 \mathrm{~A}-\mathrm{H} 14 \mathrm{C}$ & 0.9600 & $\mathrm{C} 11 \mathrm{~B}-\mathrm{H} 11 \mathrm{~F}$ & 0.9700 \\
\hline $\mathrm{O} 3^{\prime}-\mathrm{C} 9^{\prime}$ & $1.440(5)$ & $\mathrm{C} 12 \mathrm{~B}-\mathrm{C} 13 \mathrm{~B}$ & $1.495(3)$ \\
\hline $\mathrm{C} 9^{\prime}-\mathrm{C} 10^{\prime}$ & $1.490(6)$ & $\mathrm{C} 12 \mathrm{~B}-\mathrm{H} 12 \mathrm{E}$ & 0.9700 \\
\hline $\mathrm{C} 9^{\prime}-\mathrm{H} 9 \mathrm{C}$ & 0.9700 & $\mathrm{C} 12 \mathrm{~B}-\mathrm{H} 12 \mathrm{~F}$ & 0.9700 \\
\hline
\end{tabular}




\begin{tabular}{|c|c|c|c|}
\hline C9'-H9D & 0.9700 & $\mathrm{C} 13 \mathrm{~B}-\mathrm{C} 14 \mathrm{~B}$ & $1.529(3)$ \\
\hline $\mathrm{C} 10^{\prime}-\mathrm{C} 11^{\prime}$ & $1.467(7)$ & $\mathrm{C} 13 \mathrm{~B}-\mathrm{H} 13 \mathrm{E}$ & 0.9700 \\
\hline $\mathrm{C} 10^{\prime}-\mathrm{H} 10 \mathrm{C}$ & 0.9700 & $\mathrm{C} 13 \mathrm{~B}-\mathrm{H} 13 \mathrm{~F}$ & 0.9700 \\
\hline $\mathrm{C} 10^{\prime}-\mathrm{H} 10 \mathrm{D}$ & 0.9700 & $\mathrm{C} 14 \mathrm{~B}-\mathrm{H} 14 \mathrm{G}$ & 0.9600 \\
\hline $\mathrm{C} 11^{\prime}-\mathrm{C} 12^{\prime}$ & $1.566(7)$ & $\mathrm{C} 14 \mathrm{~B}-\mathrm{H} 14 \mathrm{H}$ & 0.9600 \\
\hline $\mathrm{C} 11^{\prime}-\mathrm{H} 11 \mathrm{C}$ & 0.9700 & $\mathrm{C} 14 \mathrm{~B}-\mathrm{H} 14 \mathrm{I}$ & 0.9600 \\
\hline $\mathrm{C} 2 \mathrm{~A}-\mathrm{C} 1 \mathrm{~A}-\mathrm{C} 6 \mathrm{~A}$ & $119.29(19)$ & $\mathrm{H} 11 \mathrm{C}-\mathrm{C} 11^{\prime}-\mathrm{H} 11 \mathrm{D}$ & 107.5 \\
\hline $\mathrm{C} 2 \mathrm{~A}-\mathrm{C} 1 \mathrm{~A}-\mathrm{C} 7 \mathrm{~A}$ & $121.7(2)$ & $\mathrm{C} 13^{\prime}-\mathrm{C} 12^{\prime}-\mathrm{C} 11^{\prime}$ & $114.4(6)$ \\
\hline $\mathrm{C} 6 \mathrm{~A}-\mathrm{C} 1 \mathrm{~A}-\mathrm{C} 7 \mathrm{~A}$ & $118.96(19)$ & $\mathrm{C} 13^{\prime}-\mathrm{C} 12^{\prime}-\mathrm{H} 12 \mathrm{C}$ & 108.6 \\
\hline $\mathrm{C} 1 \mathrm{~A}-\mathrm{C} 2 \mathrm{~A}-\mathrm{C} 3 \mathrm{~A}$ & $120.0(2)$ & $\mathrm{C} 11^{\prime}-\mathrm{C} 12^{\prime}-\mathrm{H} 12 \mathrm{C}$ & 108.6 \\
\hline $\mathrm{C} 1 \mathrm{~A}-\mathrm{C} 2 \mathrm{~A}-\mathrm{H} 2 \mathrm{~A}$ & 120.0 & $\mathrm{C} 13^{\prime}-\mathrm{C} 12^{\prime}-\mathrm{H} 12 \mathrm{D}$ & 108.6 \\
\hline $\mathrm{C} 3 \mathrm{~A}-\mathrm{C} 2 \mathrm{~A}-\mathrm{H} 2 \mathrm{~A}$ & 120.0 & $\mathrm{C} 11^{\prime}-\mathrm{C} 12^{\prime}-\mathrm{H} 12 \mathrm{D}$ & 108.6 \\
\hline $\mathrm{C} 4 \mathrm{~A}-\mathrm{C} 3 \mathrm{~A}-\mathrm{C} 2 \mathrm{~A}$ & $120.3(2)$ & $\mathrm{H} 12 \mathrm{C}-\mathrm{C} 12^{\prime}-\mathrm{H} 12 \mathrm{D}$ & 107.6 \\
\hline $\mathrm{C} 4 \mathrm{~A}-\mathrm{C} 3 \mathrm{~A}-\mathrm{H} 3 \mathrm{~A}$ & 119.8 & $\mathrm{C} 12^{\prime}-\mathrm{C} 13^{\prime}-\mathrm{C} 14^{\prime}$ & $112.4(6)$ \\
\hline $\mathrm{C} 2 \mathrm{~A}-\mathrm{C} 3 \mathrm{~A}-\mathrm{H} 3 \mathrm{~A}$ & 119.8 & $\mathrm{C} 12^{\prime}-\mathrm{C} 13^{\prime}-\mathrm{H} 13 \mathrm{C}$ & 109.1 \\
\hline $\mathrm{C} 3 \mathrm{~A}-\mathrm{C} 4 \mathrm{~A}-\mathrm{O} 3^{\prime}$ & $125.2(2)$ & $\mathrm{C} 14^{\prime}-\mathrm{C} 13^{\prime}-\mathrm{H} 13 \mathrm{C}$ & 109.1 \\
\hline $\mathrm{C} 3 \mathrm{~A}-\mathrm{C} 4 \mathrm{~A}-\mathrm{O} 3 \mathrm{~A}$ & $125.2(2)$ & $\mathrm{C} 12^{\prime}-\mathrm{C} 13^{\prime}-\mathrm{H} 13 \mathrm{D}$ & 109.1 \\
\hline $\mathrm{C} 3 \mathrm{~A}-\mathrm{C} 4 \mathrm{~A}-\mathrm{C} 5 \mathrm{~A}$ & $120.36(19)$ & $\mathrm{C} 14^{\prime}-\mathrm{C} 13^{\prime}-\mathrm{H} 13 \mathrm{D}$ & 109.1 \\
\hline $\mathrm{O} 3^{\prime}-\mathrm{C} 4 \mathrm{~A}-\mathrm{C} 5 \mathrm{~A}$ & $114.4(2)$ & $\mathrm{H} 13 \mathrm{C}-\mathrm{C} 13^{\prime}-\mathrm{H} 13 \mathrm{D}$ & 107.9 \\
\hline $\mathrm{O} 3 \mathrm{~A}-\mathrm{C} 4 \mathrm{~A}-\mathrm{C} 5 \mathrm{~A}$ & $114.4(2)$ & $\mathrm{C} 13^{\prime}-\mathrm{C} 14^{\prime}-\mathrm{H} 14 \mathrm{D}$ & 109.5 \\
\hline $\mathrm{O} 2 \mathrm{~A}-\mathrm{C} 5 \mathrm{~A}-\mathrm{C} 6 \mathrm{~A}$ & $119.2(2)$ & $\mathrm{C} 13^{\prime}-\mathrm{C} 14^{\prime}-\mathrm{H} 14 \mathrm{E}$ & 109.5 \\
\hline $\mathrm{O} 2 \mathrm{~A}-\mathrm{C} 5 \mathrm{~A}-\mathrm{C} 4 \mathrm{~A}$ & $121.90(19)$ & $\mathrm{H} 14 \mathrm{D}-\mathrm{C} 14^{\prime}-\mathrm{H} 14 \mathrm{E}$ & 109.5 \\
\hline $\mathrm{C} 6 \mathrm{~A}-\mathrm{C} 5 \mathrm{~A}-\mathrm{C} 4 \mathrm{~A}$ & $118.9(2)$ & $\mathrm{C} 13^{\prime}-\mathrm{C} 14^{\prime}-\mathrm{H} 14 \mathrm{~F}$ & 109.5 \\
\hline $\mathrm{C} 5 \mathrm{~A}-\mathrm{C} 6 \mathrm{~A}-\mathrm{C} 1 \mathrm{~A}$ & $121.1(2)$ & $\mathrm{H} 14 \mathrm{D}-\mathrm{C} 14^{\prime}-\mathrm{H} 14 \mathrm{~F}$ & 109.5 \\
\hline $\mathrm{C} 5 \mathrm{~A}-\mathrm{C} 6 \mathrm{~A}-\mathrm{H} 6 \mathrm{~A}$ & 119.4 & $\mathrm{H} 14 \mathrm{E}-\mathrm{C} 14^{\prime}-\mathrm{H} 14 \mathrm{~F}$ & 109.5 \\
\hline $\mathrm{C} 1 \mathrm{~A}-\mathrm{C} 6 \mathrm{~A}-\mathrm{H} 6 \mathrm{~A}$ & 119.4 & $\mathrm{C} 2 \mathrm{~B}-\mathrm{C} 1 \mathrm{~B}-\mathrm{C} 6 \mathrm{~B}$ & $118.83(19)$ \\
\hline $\mathrm{O} 1 \mathrm{~A}-\mathrm{C} 7 \mathrm{~A}-\mathrm{C} 1 \mathrm{~A}$ & $119.7(2)$ & $\mathrm{C} 2 \mathrm{~B}-\mathrm{C} 1 \mathrm{~B}-\mathrm{C} 7 \mathrm{~B}$ & $121.6(2)$ \\
\hline $\mathrm{O} 1 \mathrm{~A}-\mathrm{C} 7 \mathrm{~A}-\mathrm{C} 8 \mathrm{~A}$ & $120.8(2)$ & $\mathrm{C} 6 \mathrm{~B}-\mathrm{C} 1 \mathrm{~B}-\mathrm{C} 7 \mathrm{~B}$ & $119.5(2)$ \\
\hline $\mathrm{C} 1 \mathrm{~A}-\mathrm{C} 7 \mathrm{~A}-\mathrm{C} 8 \mathrm{~A}$ & $119.5(2)$ & $\mathrm{C} 1 \mathrm{~B}-\mathrm{C} 2 \mathrm{~B}-\mathrm{C} 3 \mathrm{~B}$ & $120.8(2)$ \\
\hline $\mathrm{C} 7 \mathrm{~A}-\mathrm{C} 8 \mathrm{~A}-\mathrm{H} 8 \mathrm{AA}$ & 109.5 & $\mathrm{C} 1 \mathrm{~B}-\mathrm{C} 2 \mathrm{~B}-\mathrm{H} 2 \mathrm{~B}$ & 119.6 \\
\hline $\mathrm{C} 7 \mathrm{~A}-\mathrm{C} 8 \mathrm{~A}-\mathrm{H} 8 \mathrm{AB}$ & 109.5 & $\mathrm{C} 3 \mathrm{~B}-\mathrm{C} 2 \mathrm{~B}-\mathrm{H} 2 \mathrm{~B}$ & 119.6 \\
\hline $\mathrm{H} 8 \mathrm{AA}-\mathrm{C} 8 \mathrm{~A}-\mathrm{H} 8 \mathrm{AB}$ & 109.5 & $\mathrm{C} 4 \mathrm{~B}-\mathrm{C} 3 \mathrm{~B}-\mathrm{C} 2 \mathrm{~B}$ & $119.9(2)$ \\
\hline $\mathrm{C} 7 \mathrm{~A}-\mathrm{C} 8 \mathrm{~A}-\mathrm{H} 8 \mathrm{AC}$ & 109.5 & $\mathrm{C} 4 \mathrm{~B}-\mathrm{C} 3 \mathrm{~B}-\mathrm{H} 3 \mathrm{~B}$ & 120.1 \\
\hline $\mathrm{H} 8 \mathrm{AA}-\mathrm{C} 8 \mathrm{~A}-\mathrm{H} 8 \mathrm{AC}$ & 109.5 & $\mathrm{C} 2 \mathrm{~B}-\mathrm{C} 3 \mathrm{~B}-\mathrm{H} 3 \mathrm{~B}$ & 120.1 \\
\hline $\mathrm{H} 8 \mathrm{AB}-\mathrm{C} 8 \mathrm{~A}-\mathrm{H} 8 \mathrm{AC}$ & 109.5 & $\mathrm{O} 3 \mathrm{~B}-\mathrm{C} 4 \mathrm{~B}-\mathrm{C} 3 \mathrm{~B}$ & $125.6(2)$ \\
\hline $\mathrm{C} 5 \mathrm{~A}-\mathrm{O} 2 \mathrm{~A}-\mathrm{H} 2 \mathrm{OA}$ & $114.2(17)$ & $\mathrm{O} 3 \mathrm{~B}-\mathrm{C} 4 \mathrm{~B}-\mathrm{C} 5 \mathrm{~B}$ & $114.38(19)$ \\
\hline $\mathrm{C} 4 \mathrm{~A}-\mathrm{O} 3 \mathrm{~A}-\mathrm{C} 9 \mathrm{~A}$ & $115.5(2)$ & $\mathrm{C} 3 \mathrm{~B}-\mathrm{C} 4 \mathrm{~B}-\mathrm{C} 5 \mathrm{~B}$ & $120.00(19)$ \\
\hline $\mathrm{O} 3 \mathrm{~A}-\mathrm{C} 9 \mathrm{~A}-\mathrm{C} 10 \mathrm{~A}$ & $110.2(4)$ & $\mathrm{O} 2 \mathrm{~B}-\mathrm{C} 5 \mathrm{~B}-\mathrm{C} 6 \mathrm{~B}$ & $119.00(19)$ \\
\hline $\mathrm{O} 3 \mathrm{~A}-\mathrm{C} 9 \mathrm{~A}-\mathrm{H} 9 \mathrm{AA}$ & 109.6 & $\mathrm{O} 2 \mathrm{~B}-\mathrm{C} 5 \mathrm{~B}-\mathrm{C} 4 \mathrm{~B}$ & $121.58(18)$ \\
\hline $\mathrm{C} 10 \mathrm{~A}-\mathrm{C} 9 \mathrm{~A}-\mathrm{H} 9 \mathrm{AA}$ & 109.6 & $\mathrm{C} 6 \mathrm{~B}-\mathrm{C} 5 \mathrm{~B}-\mathrm{C} 4 \mathrm{~B}$ & $119.4(2)$ \\
\hline $\mathrm{O} 3 \mathrm{~A}-\mathrm{C} 9 \mathrm{~A}-\mathrm{H} 9 \mathrm{AB}$ & 109.6 & $\mathrm{C} 5 \mathrm{~B}-\mathrm{C} 6 \mathrm{~B}-\mathrm{C} 1 \mathrm{~B}$ & $121.0(2)$ \\
\hline $\mathrm{C} 10 \mathrm{~A}-\mathrm{C} 9 \mathrm{~A}-\mathrm{H} 9 \mathrm{AB}$ & 109.6 & $\mathrm{C} 5 \mathrm{~B}-\mathrm{C} 6 \mathrm{~B}-\mathrm{H} 6 \mathrm{~B}$ & 119.5 \\
\hline $\mathrm{H} 9 \mathrm{AA}-\mathrm{C} 9 \mathrm{~A}-\mathrm{H} 9 \mathrm{AB}$ & 108.1 & $\mathrm{C} 1 \mathrm{~B}-\mathrm{C} 6 \mathrm{~B}-\mathrm{H} 6 \mathrm{~B}$ & 119.5 \\
\hline $\mathrm{C} 11 \mathrm{~A}-\mathrm{C} 10 \mathrm{~A}-\mathrm{C} 9 \mathrm{~A}$ & $114.5(5)$ & $\mathrm{O} 1 \mathrm{~B}-\mathrm{C} 7 \mathrm{~B}-\mathrm{C} 1 \mathrm{~B}$ & $119.9(2)$ \\
\hline $\mathrm{C} 11 \mathrm{~A}-\mathrm{C} 10 \mathrm{~A}-\mathrm{H} 10 \mathrm{~A}$ & 108.6 & $\mathrm{O} 1 \mathrm{~B}-\mathrm{C} 7 \mathrm{~B}-\mathrm{C} 8 \mathrm{~B}$ & $120.1(2)$ \\
\hline $\mathrm{C} 9 \mathrm{~A}-\mathrm{C} 10 \mathrm{~A}-\mathrm{H} 10 \mathrm{~A}$ & 108.6 & $\mathrm{C} 1 \mathrm{~B}-\mathrm{C} 7 \mathrm{~B}-\mathrm{C} 8 \mathrm{~B}$ & $120.0(2)$ \\
\hline $\mathrm{C} 11 \mathrm{~A}-\mathrm{C} 10 \mathrm{~A}-\mathrm{H} 10 \mathrm{~B}$ & 108.6 & $\mathrm{C} 7 \mathrm{~B}-\mathrm{C} 8 \mathrm{~B}-\mathrm{H} 8 \mathrm{BA}$ & 109.5 \\
\hline
\end{tabular}




\begin{tabular}{|c|c|}
\hline $\mathrm{C} 9 \mathrm{~A}-\mathrm{C} 10 \mathrm{~A}-\mathrm{H} 10 \mathrm{~B}$ & 108.6 \\
\hline $\mathrm{H} 10 \mathrm{~A}-\mathrm{C} 10 \mathrm{~A}-\mathrm{H} 10 \mathrm{~B}$ & 107.6 \\
\hline $\mathrm{C} 10 \mathrm{~A}-\mathrm{C} 11 \mathrm{~A}-\mathrm{C} 12 \mathrm{~A}$ & $111.9(5)$ \\
\hline $\mathrm{C} 10 \mathrm{~A}-\mathrm{C} 11 \mathrm{~A}-\mathrm{H} 11 \mathrm{~A}$ & 109.2 \\
\hline $\mathrm{C} 12 \mathrm{~A}-\mathrm{C} 11 \mathrm{~A}-\mathrm{H} 11 \mathrm{~A}$ & 109.2 \\
\hline $\mathrm{C} 10 \mathrm{~A}-\mathrm{C} 11 \mathrm{~A}-\mathrm{H} 11 \mathrm{~B}$ & 109.2 \\
\hline $\mathrm{C} 12 \mathrm{~A}-\mathrm{C} 11 \mathrm{~A}-\mathrm{H} 11 \mathrm{~B}$ & 109.2 \\
\hline $\mathrm{H} 11 \mathrm{~A}-\mathrm{C} 11 \mathrm{~A}-\mathrm{H} 11 \mathrm{~B}$ & 107.9 \\
\hline $\mathrm{C} 13 \mathrm{~A}-\mathrm{C} 12 \mathrm{~A}-\mathrm{C} 11 \mathrm{~A}$ & $112.5(5$ \\
\hline $\mathrm{C} 13 \mathrm{~A}-\mathrm{C} 12 \mathrm{~A}-\mathrm{H} 12 \mathrm{~A}$ & 109.1 \\
\hline $\mathrm{C} 11 \mathrm{~A}-\mathrm{C} 12 \mathrm{~A}-\mathrm{H} 12 \mathrm{~A}$ & 109.1 \\
\hline $\mathrm{C} 13 \mathrm{~A}-\mathrm{C} 12 \mathrm{~A}-\mathrm{H} 12 \mathrm{~B}$ & 109.1 \\
\hline $\mathrm{C} 11 \mathrm{~A}-\mathrm{C} 12 \mathrm{~A}-\mathrm{H} 12 \mathrm{~B}$ & 109.1 \\
\hline $\mathrm{H} 12 \mathrm{~A}-\mathrm{C} 12 \mathrm{~A}-\mathrm{H} 12 \mathrm{~B}$ & 107.8 \\
\hline $\mathrm{C} 12 \mathrm{~A}-\mathrm{C} 13 \mathrm{~A}-\mathrm{C} 14 \mathrm{~A}$ & $111.7(4$ \\
\hline $\mathrm{C} 12 \mathrm{~A}-\mathrm{C} 13 \mathrm{~A}-\mathrm{H} 13 \mathrm{~A}$ & 109.3 \\
\hline $\mathrm{C} 14 \mathrm{~A}-\mathrm{C} 13 \mathrm{~A}-\mathrm{H} 13 \mathrm{~A}$ & 109.3 \\
\hline $\mathrm{C} 12 \mathrm{~A}-\mathrm{C} 13 \mathrm{~A}-\mathrm{H} 13 \mathrm{~B}$ & 109.3 \\
\hline $\mathrm{C} 14 \mathrm{~A}-\mathrm{C} 13 \mathrm{~A}-\mathrm{H} 13 \mathrm{~B}$ & 109.3 \\
\hline $\mathrm{H} 13 \mathrm{~A}-\mathrm{C} 13 \mathrm{~A}-\mathrm{H} 13 \mathrm{~B}$ & 107.9 \\
\hline $\mathrm{C} 13 \mathrm{~A}-\mathrm{C} 14 \mathrm{~A}-\mathrm{H} 14 \mathrm{~A}$ & 109.5 \\
\hline $\mathrm{C} 13 \mathrm{~A}-\mathrm{C} 14 \mathrm{~A}-\mathrm{H} 14 \mathrm{~B}$ & 109.5 \\
\hline $\mathrm{H} 14 \mathrm{~A}-\mathrm{C} 14 \mathrm{~A}-\mathrm{H} 14 \mathrm{~B}$ & 109.5 \\
\hline $\mathrm{C} 13 \mathrm{~A}-\mathrm{C} 14 \mathrm{~A}-\mathrm{H} 14 \mathrm{C}$ & 109.5 \\
\hline $\mathrm{H} 14 \mathrm{~A}-\mathrm{C} 14 \mathrm{~A}-\mathrm{H} 14 \mathrm{C}$ & 109.5 \\
\hline $\mathrm{H} 14 \mathrm{~B}-\mathrm{C} 14 \mathrm{~A}-\mathrm{H} 14 \mathrm{C}$ & 109.5 \\
\hline $\mathrm{C} 4 \mathrm{~A}-\mathrm{O} 3^{\prime}-\mathrm{C}^{\prime}$ & 121.4( \\
\hline $\mathrm{O}^{\prime}-\mathrm{C} 9^{\prime}-\mathrm{C} 10^{\prime}$ & $110.8(5$ \\
\hline $\mathrm{O}^{\prime}-\mathrm{C} 9^{\prime}-\mathrm{H} 9 \mathrm{C}$ & 109.5 \\
\hline $\mathrm{C} 10^{\prime}-\mathrm{C}^{\prime}-\mathrm{H} 9 \mathrm{C}$ & 109.5 \\
\hline $\mathrm{O}^{\prime}-\mathrm{C} 9^{\prime}-\mathrm{H} 9 \mathrm{D}$ & 109.5 \\
\hline $\mathrm{C} 10^{\prime}-\mathrm{C} 9^{\prime}-\mathrm{H} 9 \mathrm{D}$ & 109.5 \\
\hline $\mathrm{H} 9 \mathrm{C}-\mathrm{C} 9^{\prime}-\mathrm{H} 9 \mathrm{D}$ & 108.1 \\
\hline $\mathrm{C} 9^{\prime}-\mathrm{C} 10^{\prime}-\mathrm{C} 11^{\prime}$ & $111.7(6$ \\
\hline $\mathrm{C} 9^{\prime}-\mathrm{C} 10^{\prime}-\mathrm{H} 10 \mathrm{C}$ & 109.3 \\
\hline $\mathrm{C} 11^{\prime}-\mathrm{C} 10^{\prime}-\mathrm{H} 10 \mathrm{C}$ & 109.3 \\
\hline $\mathrm{C}^{\prime}-\mathrm{C} 10^{\prime}-\mathrm{H} 10 \mathrm{D}$ & 109.3 \\
\hline $\mathrm{C} 11^{\prime}-\mathrm{C} 10^{\prime}-\mathrm{H} 10 \mathrm{D}$ & 109.3 \\
\hline $\mathrm{H} 10 \mathrm{C}-\mathrm{C} 10^{\prime}-\mathrm{H} 10 \mathrm{D}$ & 107.9 \\
\hline $\mathrm{C} 12^{\prime}-\mathrm{C} 11^{\prime}-\mathrm{C} 10^{\prime}$ & $114.9(6$ \\
\hline $\mathrm{C} 12^{\prime}-\mathrm{C} 11^{\prime}-\mathrm{H} 11 \mathrm{C}$ & 108.5 \\
\hline $\mathrm{C} 10^{\prime}-\mathrm{C} 11^{\prime}-\mathrm{H} 11 \mathrm{C}$ & 108.5 \\
\hline $\mathrm{C} 12^{\prime}-\mathrm{C} 11^{\prime}-\mathrm{H} 11 \mathrm{D}$ & 108.5 \\
\hline $\mathrm{C} 10^{\prime}-\mathrm{C} 11^{\prime}-\mathrm{H} 11 \mathrm{D}$ & 108.5 \\
\hline
\end{tabular}

\begin{tabular}{|c|c|}
\hline $\mathrm{C} 7 \mathrm{~B}-\mathrm{C} 8 \mathrm{~B}-\mathrm{H} 8 \mathrm{BB}$ & 109.5 \\
\hline $\mathrm{H} 8 \mathrm{BA}-\mathrm{C} 8 \mathrm{~B}-\mathrm{H} 8 \mathrm{BB}$ & 109.5 \\
\hline $\mathrm{C} 7 \mathrm{~B}-\mathrm{C} 8 \mathrm{~B}-\mathrm{H} 8 \mathrm{BC}$ & 109.5 \\
\hline $\mathrm{H} 8 \mathrm{BA}-\mathrm{C} 8 \mathrm{~B}-\mathrm{H} 8 \mathrm{BC}$ & 109.5 \\
\hline $\mathrm{H} 8 \mathrm{BB}-\mathrm{C} 8 \mathrm{~B}-\mathrm{H} 8 \mathrm{BC}$ & 109.5 \\
\hline $\mathrm{C} 5 \mathrm{~B}-\mathrm{O} 2 \mathrm{~B}-\mathrm{H} 2 \mathrm{OB}$ & $111.0(18)$ \\
\hline $\mathrm{C} 4 \mathrm{~B}-\mathrm{O} 3 \mathrm{~B}-\mathrm{C} 9 \mathrm{~B}$ & $117.76(17)$ \\
\hline $\mathrm{O} 3 \mathrm{~B}-\mathrm{C} 9 \mathrm{~B}-\mathrm{C} 10 \mathrm{~B}$ & $108.61(18)$ \\
\hline $\mathrm{O} 3 \mathrm{~B}-\mathrm{C} 9 \mathrm{~B}-\mathrm{H} 9 \mathrm{BA}$ & 110.0 \\
\hline $\mathrm{C} 10 \mathrm{~B}-\mathrm{C} 9 \mathrm{~B}-\mathrm{H} 9 \mathrm{BA}$ & 110.0 \\
\hline $\mathrm{O} 3 \mathrm{~B}-\mathrm{C} 9 \mathrm{~B}-\mathrm{H} 9 \mathrm{BB}$ & 110.0 \\
\hline $\mathrm{C} 10 \mathrm{~B}-\mathrm{C} 9 \mathrm{~B}-\mathrm{H} 9 \mathrm{BB}$ & 110.0 \\
\hline $\mathrm{H} 9 \mathrm{BA}-\mathrm{C} 9 \mathrm{~B}-\mathrm{H} 9 \mathrm{BB}$ & 108.3 \\
\hline $\mathrm{C} 9 \mathrm{~B}-\mathrm{C} 10 \mathrm{~B}-\mathrm{C} 11 \mathrm{~B}$ & $114.51(19)$ \\
\hline $\mathrm{C} 9 \mathrm{~B}-\mathrm{C} 10 \mathrm{~B}-\mathrm{H} 10 \mathrm{E}$ & 108.6 \\
\hline $\mathrm{C} 11 \mathrm{~B}-\mathrm{C} 10 \mathrm{~B}-\mathrm{H} 10 \mathrm{E}$ & 108.6 \\
\hline $\mathrm{C} 9 \mathrm{~B}-\mathrm{C} 10 \mathrm{~B}-\mathrm{H} 10 \mathrm{~F}$ & 108.6 \\
\hline $\mathrm{C} 11 \mathrm{~B}-\mathrm{C} 10 \mathrm{~B}-\mathrm{H} 10 \mathrm{~F}$ & 108.6 \\
\hline $\mathrm{H} 10 \mathrm{E}-\mathrm{C} 10 \mathrm{~B}-\mathrm{H} 10 \mathrm{~F}$ & 107.6 \\
\hline $\mathrm{C} 10 \mathrm{~B}-\mathrm{C} 11 \mathrm{~B}-\mathrm{C} 12 \mathrm{~B}$ & $111.25(19)$ \\
\hline $\mathrm{C} 10 \mathrm{~B}-\mathrm{C} 11 \mathrm{~B}-\mathrm{H} 11 \mathrm{E}$ & 109.4 \\
\hline $\mathrm{C} 12 \mathrm{~B}-\mathrm{C} 11 \mathrm{~B}-\mathrm{H} 11 \mathrm{E}$ & 109.4 \\
\hline $\mathrm{C} 10 \mathrm{~B}-\mathrm{C} 11 \mathrm{~B}-\mathrm{H} 11 \mathrm{~F}$ & 109.4 \\
\hline $\mathrm{C} 12 \mathrm{~B}-\mathrm{C} 11 \mathrm{~B}-\mathrm{H} 11 \mathrm{~F}$ & 109.4 \\
\hline $\mathrm{H} 11 \mathrm{E}-\mathrm{C} 11 \mathrm{~B}-\mathrm{H} 11 \mathrm{~F}$ & 108.0 \\
\hline $\mathrm{C} 13 \mathrm{~B}-\mathrm{C} 12 \mathrm{~B}-\mathrm{C} 11 \mathrm{~B}$ & $115.3(2)$ \\
\hline $\mathrm{C} 13 \mathrm{~B}-\mathrm{C} 12 \mathrm{~B}-\mathrm{H} 12 \mathrm{E}$ & 108.5 \\
\hline $\mathrm{C} 11 \mathrm{~B}-\mathrm{C} 12 \mathrm{~B}-\mathrm{H} 12 \mathrm{E}$ & 108.5 \\
\hline $\mathrm{C} 13 \mathrm{~B}-\mathrm{C} 12 \mathrm{~B}-\mathrm{H} 12 \mathrm{~F}$ & 108.5 \\
\hline $\mathrm{C} 11 \mathrm{~B}-\mathrm{C} 12 \mathrm{~B}-\mathrm{H} 12 \mathrm{~F}$ & 108.5 \\
\hline $\mathrm{H} 12 \mathrm{E}-\mathrm{C} 12 \mathrm{~B}-\mathrm{H} 12 \mathrm{~F}$ & 107.5 \\
\hline $\mathrm{C} 12 \mathrm{~B}-\mathrm{C} 13 \mathrm{~B}-\mathrm{C} 14 \mathrm{~B}$ & $111.7(2)$ \\
\hline $\mathrm{C} 12 \mathrm{~B}-\mathrm{C} 13 \mathrm{~B}-\mathrm{H} 13 \mathrm{E}$ & 109.3 \\
\hline $\mathrm{C} 14 \mathrm{~B}-\mathrm{C} 13 \mathrm{~B}-\mathrm{H} 13 \mathrm{E}$ & 109.3 \\
\hline $\mathrm{C} 12 \mathrm{~B}-\mathrm{C} 13 \mathrm{~B}-\mathrm{H} 13 \mathrm{~F}$ & 109.3 \\
\hline $\mathrm{C} 14 \mathrm{~B}-\mathrm{C} 13 \mathrm{~B}-\mathrm{H} 13 \mathrm{~F}$ & 109.3 \\
\hline $\mathrm{H} 13 \mathrm{E}-\mathrm{C} 13 \mathrm{~B}-\mathrm{H} 13 \mathrm{~F}$ & 107.9 \\
\hline $\mathrm{C} 13 \mathrm{~B}-\mathrm{C} 14 \mathrm{~B}-\mathrm{H} 14 \mathrm{G}$ & 109.5 \\
\hline $\mathrm{C} 13 \mathrm{~B}-\mathrm{C} 14 \mathrm{~B}-\mathrm{H} 14 \mathrm{H}$ & 109.5 \\
\hline $\mathrm{H} 14 \mathrm{G}-\mathrm{C} 14 \mathrm{~B}-\mathrm{H} 14 \mathrm{H}$ & 109.5 \\
\hline $\mathrm{C} 13 \mathrm{~B}-\mathrm{C} 14 \mathrm{~B}-\mathrm{H} 14 \mathrm{I}$ & 109.5 \\
\hline $\mathrm{H} 14 \mathrm{G}-\mathrm{C} 14 \mathrm{~B}-\mathrm{H} 14 \mathrm{I}$ & 109.5 \\
\hline $\mathrm{H} 14 \mathrm{H}-\mathrm{C} 14 \mathrm{~B}-\mathrm{H} 14 \mathrm{I}$ & 109.5 \\
\hline
\end{tabular}


supporting information

Hydrogen-bond geometry $\left(A,{ }^{\circ}\right)$

\begin{tabular}{lllll}
\hline$D-\mathrm{H} \cdots A$ & $D-\mathrm{H}$ & $\mathrm{H} \cdots A$ & $D \cdots A$ & $D-\mathrm{H} \cdots A$ \\
\hline $\mathrm{O} 2 A-\mathrm{H} 2 O A \cdots \mathrm{O} 1 B$ & $0.96(3)$ & $1.83(3)$ & $2.735(2)$ & $156(3)$ \\
$\mathrm{O} 2 B-\mathrm{H} 2 O B \cdots \mathrm{O} 1 A^{\mathrm{i}}$ & $0.92(3)$ & $1.89(3)$ & $2.779(2)$ & $161(3)$ \\
\hline
\end{tabular}

Symmetry code: (i) $x,-y+1 / 2, z-1 / 2$. 